\title{
LA CORTE SUPREMA DE JUSTICIA ARGENTINA Y SU ROL EN LA ARTICULACIÓN DEL DERECHO INTERNACIONAL DE LOS DERECHOS HUMANOS Y EL DERECHO INTERNO
}

\begin{abstract}
POR VÍCTOR BAZÁN

Profesor Titular Efectivo de las asignaturas Derecho Constitucional y Derecho Internacional Público de la Facultad de Derecho y Ciencias Sociales de la Universidad Católica de Cuyo (San Juan, Argentina)
\end{abstract}

\section{PLAN DEL TRABAJO}

Desde un plano general de análisis, puede afirmarse que los puntos de contacto (en no pocas ocasiones tensionales) entre el derecho internacional de los derechos humanos y el derecho interno se multiplican, patentizándose la necesidad de lograr una pacífica articulación de tales fuentes mediante su retroalimentación y complementariedad para procurar la solidificación del sistema general de derechos, lo que es tan sencillo de predicar discursivamente como arduo de concretar en la realidad fáctica.

Bajo esa óptica, y ya en particular acerca del escenario jurídico argentino (aunque con algunas referencias al derecho comparado), nos proponemos analizar la evolución jurisprudencial y normativa de distintos aspectos que la interacción del derecho internacional de los derechos humanos y el derecho doméstico generan y el rol que la Corte Suprema de Justicia de la Nación (en 
trance de convertirse en un tribunal constitucional al menos desde el plano material) ha tenido en dichos menesteres: la ubicación jerárquica de los instrumentos internacionales sobre la materia en el contexto nacional, la cotización jurídica interna que se le asigna a los pronunciamientos de la Comisión y la Corte Interamericanas de Derechos Humanos, y la siempre sensible problemática de la ejecución en sede nacional de las sentencias de dicho tribunal interamericano; temas, todos, que forman parte sustancial de los retos más trascendentes a los que se enfrenta cualquier propósito verdadero de consolidación del Estado Constitucional de Derecho, sustentado axiológicamente en el respeto cabal de la democracia y los derechos fundamentales.

\section{APRECIACIONES PRELIMINARES}

De acuerdo con lo anunciado, es un dato de la realidad que la creciente trascendencia de la intersección del derecho doméstico y el derecho internacional de los derechos humanos exige una articulación de tal binomio de fuentes mediante su retroalimentación y complementariedad en pro del fortalecimiento real y no sólo declamado del sistema de derechos ${ }^{1}$.

Tales postulados no hacen sino refrendar que la cardinal problemática de los derechos humanos es una incumbencia - y debe ser una preocupación- concurrente o compartida entre las jurisdicciones estatales y la transnacional; sin olvidar, por cierto, que ésta presenta un carácter subsidiario y coadyuvante de los ordenamientos nacionales.

Consistente con lo anticipado, no está de más recordar que tanto en la fase inicial de un proceso en el que se investigue la eventual violación de derechos humanos, cuanto - en su caso- en la etapa de ejecución de una sentencia de condena internacional ${ }^{2}$, la intervención de los órganos competentes nacionales resulta ineludible.

Es que, en general, es condición inexcusable para que quede jurídicamente abierto, v.gr., el acceso al sistema interamericano ${ }^{3}$, que se haya agotado previamente la vía interna y, de manera semejante, luego de un pronunciamiento de

${ }^{1}$ En cuanto a este último aspecto, ver mutatis mutandi, Bidart Campos, GERMÁN J., El derecho constitucional humanitario, Ediar, Buenos Aires, 1996, pág. 140.

${ }^{2}$ Cfr. art. 68.2 de la Convención Americana sobre Derechos Humanos (CADH).

3 Cfr. art. 46.1.a de la CADH.

Fuera del sistema interamericano, también, por ejemplo, en el Protocolo Facultativo del Pacto Internacional de Derechos Civiles y Políticos (art. 5.2.b). 
condena de un Estado por la Corte Interamericana que aquél no cumpla en tiempo y forma, sobrevendrá para la víctima (sus familiares o representantes legales) la posibilidad de ejecutar ese decisorio ante los tribunales internos del demandado renuente.

No puede omitirse, por tanto, la necesidad de internalizar la centralidad del fenómeno que encarnan los derechos humanos y la no menor trascendencia de propiciar un ensanchamiento de las posibilidades de acceso de la persona a los mecanismos protectorios, internos o internacionales, viabilizando un útil empleo de éstos, ya que es claro que el progreso de la democracia se mide por la expansión $y$ justiciabilidad de los derechos ${ }^{4}$.

Ello, a pesar de la gran paradoja que se ha descrito con acierto expresando que aunque se profundice cada vez más una visión crítica y exista una desconfianza creciente respecto del sistema de administración de justicia, cada día crece la demanda por la justicia ${ }^{5}$. En otras palabras, mientras mayor es la crítica contra dicho sistema, mayor es también la demanda de justicia por parte de la población ${ }^{6}$.

Además, y como herramienta hermenéutica de primer orden, debe tomarse en consideración que, en el ámbito del derecho internacional, los derechos humanos son cuestiones de ius cogens o principios generales del derecho internacional, ya consuetudinario, ya convencional ${ }^{7}$.

Desde una perspectiva genérica, puede observarse que tanto el art. 38 del Estatuto del Tribunal Permanente de Justicia Internacional de la Sociedad de las Naciones cuanto el mismo número de artículo correspondiente al Estatuto de la actual Corte Internacional de Justicia (que sustituyó a aquel Tribunal Permanente) de la Organización de Naciones Unidas, han establecido la aplica-

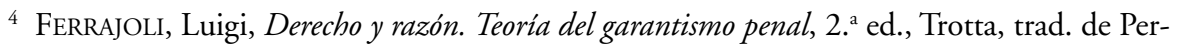
fecto Andrés Ibáñez y otros, Madrid, 1997, pág. 918.

5 Cfr. Bolívar, Ligia, "Justicia y acceso. Los problemas y las soluciones», Revista del Instituto Interamericano de Derechos Humanos, Nos. 32-33, Edición especial sobre 'Acceso a la Justicia', per. julio 2001-junio 2002, Instituto Interamericano de Derechos Humanos, San José de Costa Rica, pág. 72.

${ }^{6}$ Incluso, varios instrumentos internacionales que ostentan singular valor en el ámbito del derecho internacional de los derechos humanos, y que en Argentina han sido dotados de jerarquía constitucional, ponen de manifiesto la exigencia de que los ordenamientos domésticos aseguren el acceso a la justicia, por ejemplo, los arts. XVIII de la Declaración Americana de los Derechos y Deberes del Hombre, 8 de la Declaración Universal de Derechos Humanos, 8 de la CADH y 14 del Pacto Internacional de Derechos Civiles y Políticos (PIDCP).

7 En ese sentido, ver por ejemplo, NogueIra AlCALÁ, Humberto, Teoría y dogmática de los derechos fundamentales, Instituto de Investigaciones Jurídicas, Universidad Nacional Autónoma de México, México, D.F., 2003, pág. 394. 
ción — inter alia - de «los principios generales del Derecho reconocidos por las naciones civilizadas", que — en definitiva — son los aceptados por las naciones in foro domestico. En consecuencia, todos los Estados que integran la comunidad internacional deben cumplir con tales pautas y con las normas de derecho convencional y consuetudinario que se establezcan sobre la base de aquéllas, pues los principios reconocidos por las naciones civilizadas son «obligatorios para todos los Estados incluso fuera de todo vínculo convencional, ${ }^{8}$ [remarcado añadido], razón por la cual la circunstancia de que un Estado no haya ratificado la Convención de Viena sobre el Derecho de los Tratados no lo habilita jurídicamente a eximirse del deber de observancia dado que se está ante la presencia de normas internacionales de ius cogens, es decir, de práctica generalizada y obligatoria.

Todo lo mencionado precedentemente lleva a dirigir el punto de mira hacia la interacción de los tribunales nacionales y los internacionales en materia de derechos humanos, que se mueve al compás de una lógica compleja y genera una trama de relaciones no pocas veces conflictiva.

Éstos y otros condimentos de una cuestión de actualidad permanente, nos llevan a reiterar que la consolidación de una convergencia sustentable de ambas instancias jurisdiccionales se presenta como una necesidad inaplazable y pasa a simbolizar uno de los retos cruciales a los que se enfrenta la cabal protección del ser humano en el ámbito internacional.

$Y$ en esta dinámica, los jueces nacionales se enfrentan a una nueva realidad a la que deben amoldarse, caracterizada — inter alia - por la ampliación del parámetro de control de constitucionalidad de la normativa infraconstitucional, la que —además de la Ley Fundamental— deberá ser cotejada con los instrumentos internacionales que conforman el estatuto básico de los derechos humanos.

Es así indudable que la creciente evolución del derecho internacional de los derechos humanos diversifica los retos que se posan sobre la magistratura judicial, entre los que se cuenta la imprescindibilidad de manejar una multiplicidad de fuentes (otrora inexistentes o con una carga preceptiva entonces posible de mediatizar) y de reestudiar diversas categorías jurídicas a la luz de las pautas internacionales.

Como es de suponer, el incumplimiento de aquellas obligaciones en el plano transnacional generará la responsabilidad estatal internacional, que natural-

${ }^{8}$ Paráfrasis de una afirmación que la Corte Internacional de Justicia vertiera al evacuar la opinión consultiva de 28 de mayo de 1951: «Reservations to the Convention on the Prevention and Punishment of the Crime of Genocide», Reports of Judgements, Advisory Opinions and Orders, Leyden A. W. Sijthoff's Publishing Company, 1951, o Recueil, 1951, págs. 23/24. 
mente resultará agravada si la preterición de que se trate vehicula una infracción — por acción u omisión- a normas iusinternacionales fundamentales.

En este juego de conexiones y articulaciones entre el derecho interno y el derecho internacional de los derechos humanos, no puede pasar inadvertido que, por caso, algunas irradiaciones del art. 29 de la Convención Americana sobre Derechos Humanos (CADH) quedan plasmadas en ciertos patrones hermenéuticos por conducto de los cuales ninguna disposición de la Convención puede ser interpretada en el sentido de limitar el goce y el ejercicio de cualquier derecho o libertad que pueda estar reconocido de acuerdo con las leyes de cualquiera de los Estados Partes o de acuerdo con otra convención en que sea parte uno de dichos Estados (inc. 'b'); o no puede serlo para excluir otros derechos y garantías que son inherentes al ser humano o que se derivan de la forma democrática representativa de gobierno (inc. 'c').

Aunque sobreabundante, lo dicho apunta a relevar que ante un conflicto de interpretación o aplicación jurídicas entre una norma internacional de derechos humanos y otra interna sobre la materia, deberá en toda ocasión optarse por la solución que de modo más acabado y efectivo brinde mayor protección a los derechos humanos en juego, sea que aquélla se nutra de una fuente doméstica o de una proveniente del plano internacional.

Ello nos conduce al postulado pro homine que, según PINTO, constituye un criterio hermenéutico que informa todo el derecho de los derechos humanos, en virtud del cual se debe acudir a la norma más amplia, o a la interpretación más extensiva, cuando se trata de reconocer derechos protegidos e, inversamente, a la norma o a la interpretación más restringidas cuando se trata de establecer restricciones permanentes al ejercicio de los derechos o de suspenderlos en forma extraordinaria?.

En otras palabras, tal pauta activa la necesidad de funcionalizar el principio de protección integral de la persona humana alimentado por la premisa que indica que Constitución e instrumentos internacionales sobre derechos humanos forman un cuerpo jurídico que orienta su vigencia hacia un mismo sustrato axiológico ${ }^{10}$.

9 PINTO, Mónica, «El principio pro homine. Criterios de hermenéutica y pautas para la regulación de los derechos humanos», en ABREGÚ, Martín y COURTIS, Christian [compiladores]: La aplicación de los tratados sobre derechos humanos por los tribunales locales, Centro de Estudios Legales y Sociales, Editores del Puerto, Buenos Aires, 1997, pág. 163.

10 Aunque fuera del ámbito argentino, este último fundamento (orientación de la Constitución y los instrumentos internacionales sobre derechos humanos hacia un idéntico sustrato axiológico) fue puesto de manifiesto en un interesante precedente de la Sala Constitucional de la Cor- 


\section{LA REFORMA CONSTITUCIONAL DE 1994 Y SU IMPACTO EN EL CAMPO DE LOS DERECHOS HUMANOS}

Uno de los sectores temáticos que ha sido fuertemente impactado por la innovación constitucional de 1994, cuando menos desde el plano normológico, es sin lugar a dudas el de los derechos fundamentales.

Como algunas señales claras en tal sentido, y sin ánimo alguno de taxatividad, pueden computarse: la ampliación del plafón de derechos explícitos (v.gr., arts. 37, 41, 42 de la Constitución Nacional [en adelante: C.N.]); la literalización de los procesos constitucionales de amparo, hábeas corpus y hábeas data (art. 43 ibíd.); el diseño de un nuevo paradigma del principio de igualdad, caracterizado por la exigencia de complementación de la igualdad formal (art. 16 ibid.) con la igualdad material (artículos constitucionales 37 y 75, incs. 2. ${ }^{\circ}, 19$ y 23); y la adjudicación de jerarquía constitucional a once instrumentos internacionales en materia de derechos humanos (art. 75, inc. 22, párr. 2. ${ }^{\circ}$, ibid.), que hacen que la antigua figura de la 'pirámide' en la que su vértice superior era ocupado en solitario por la Constitución, haya devenido en una especie de 'trapecio' en cuyo plano más elevado comparten espacios en constante retroalimentación la Ley Fundamental y los documentos internacionales sobre derechos humanos con idéntica valía.

Este último factor (adjudicación de valencia constitucional a los instrumentos internacionales sobre la materia mencionada) a su vez ha generado no pocos (tampoco insignificantes) efectos directos y colaterales, entre los cuales pueden mencionarse, en lista no taxativa: la amplificación cuantitativa y cualitativa del cartabón de derechos implícitos y explícitos; la instauración de los

te Suprema de Justicia del Salvador: Sentencia 52-2003/56-2003/57/2003, de 1 de abril de 2004, "Caso inconstitucionalidad de la Ley Anti Maras».

En dicho pronunciamiento la Sala revisa y modifica algunos de sus anteriores fallos en los que analizaba la influencia del derecho internacional de los derechos humanos en el sistema de fuentes del ordenamiento jurídico salvadoreño, sentando ahora la pauta que indica que debe reconocerse que no son contrarias a la Constitución aquellas normas internacionales que sean análogas o más amplias en su reconocimiento sobre los derechos humanos, pues la Constitución, en integración con los instrumentos internacionales en la materia forman un corpus iuris que dirige su ámbito de vigencia efectiva hacia un mismo sustrato axiológico: la dignidad humana y el catálogo de los derechos fundamentales que desarrollan los valores inherentes a su personalidad, es decir, dignidad, libertad e igualdad.

El texto (resumido) de la sentencia puede consultarse en Diálogo jurisprudencial, N. ${ }^{\circ}$ 1, juliodiciembre 2006, Corte Interamericana de Derechos Humanos, Instituto Interamericano de Derechos Humanos, Universidad Nacional Autónoma de México (Instituto de Investigaciones Jurídicas) y Fundación Konrad Adenauer, México, D.F., 2006, págs. 153/163. 
principios pro homine o favor libertatis y pro actione, con los criterios hermenéuticos que vienen por añadidura: interpretación de buena fe, pacta sunt servanda y los atinentes al objeto y el fin de los tratados; la vigorización de la pauta que determina la imposibilidad de alegar la existencia o inexistencia de normas de derecho interno para dejar de cumplir compromisos internacionales; y la ineludible responsabilidad internacional en caso de incumplimiento de éstos.

Entre un significativo número de consecuencias, todo ello ha provocado - como anticipábamos - la extensión formal y material del parámetro de control de constitucionalidad, en función de lo cual la normativa infraconstitucional debe ser examinada a la luz de la Norma Básica y de los instrumentos internacionales sobre derechos humanos con valencia homóloga a ésta para verificar si supera satisfactoriamente el test de constitucionalidad.

Desde el plano formal, la anunciada extensión del canon de fiscalización constitucional se configura al haberse adjudicado valencia constitucional a un conjunto de instrumentos internacionales en materia de derechos humanos; por su parte, desde el ángulo material, se hace ostensible por la exigencia que se cierne sobre los órganos jurisdiccionales en cuanto a recurrir a los principios y valores de la Norma Superior y de los documentos internacionales sobre el campo temático citado ${ }^{11}$.

En paralelo a la citada dotación de jerarquía constitucional a un nutrido plexo de instrumentos internacionales sobre derechos humanos por la Convención Constituyente de 1994 o posteriormente por el Congreso de la Nación ${ }^{12}$, la mencionada innovación constitucional también ha producido, inter alia, la necesidad de asegurar el (remozado) principio de igualdad a través de acciones positivas y la inexcusable implicación de todas las autoridades públicas en tales menesteres, en un escenario donde es imposible perder de vista el caudal axiológico que suministra el imperativo preambular de «afianzar la justicia». Todo ello fortalece la exigibilidad y la justiciabilidad de los derechos, obliga al Estado ar-

${ }^{11} \mathrm{Al}$ respecto ver, mutatis mutandi, AJA, Eliseo y GonZÁlez BeILfuss, Markus, "Conclusiones generales», en AJA, Eliseo (editor), Las tensiones entre el Tribunal Constitucional y el legislador en la Europa actual, Ariel, Barcelona, 1998, pág. 261.

12 A la nómina primigenia de instrumentos internacionales con jerarquía constitucional originaria contenida en el art. 75 , inc. 22, párr..$^{\circ}$, de la Ley Fundamental, se han añadido, con idéntica alcurnia (aunque derivada), la Convención Interamericana sobre Desaparición Forzada de Personas (a la que se ha deparado tal calidad por medio de la Ley 24.820, publicada el 29 de mayo de 1997) y la Convención sobre la Imprescriptibilidad de los Crímenes de Guerra y de los Crímenes de Lesa Humanidad (a la que se le ha conferido esa valía mediante la Ley 25.778, B.O. de 3 de septiembre de 2003). 
gentino y lo impele a volcar todos los esfuerzos y recursos posibles en el cabal cumplimiento de las exigencias internacionales asumidas en tal ámbito.

\section{LOS JUECES Y EL ESTADO CONSTITUCIONAL DE DERECHO}

Un contexto de la magnitud descripta en el apartado anterior desnuda el sustancial compromiso adquirido por el Estado en la materia y disemina una nítida señal hacia los órganos del poder constituido (incluidos los jueces, por cierto), todos los cuales quedan alcanzados vinculatoriamente por la fuerza normativa de la Constitución, su supremacía y la de los documentos internacionales con igual magnitud a la de la Ley Fundamental.

Es claro, así, que cualquier interpretación de la preceptiva subconstitucional no podrá prescindir válidamente de dichos datos de la realidad constitucional ni soslayar la obligatoriedad de ser encauzada de conformidad con la Constitución, el derecho internacional de los derechos humanos y los pronunciamientos de la Corte Interamericana, sin eludir tampoco la fuerza preceptiva de las recomendaciones de la Comisión Interamericana y de otros órganos internacionales de supervisión en la materia.

Es preciso reiterar que el Estado contemporáneo es Estado Constitucional, en cuyo contexto la Constitución ocupa un lugar central en el sistema jurídico (junto a los instrumentos internacionales universales y regionales básicos en materia de derechos humanos con valencia homóloga a la de la Carta Fundamental) y ostenta fuerza normativa.

Para medir en un plano general de discusión la trascendencia de la labor interpretativa a cargo de los tribunales, no debe olvidarse que el aseguramiento de la primacía constitucional —en interacción con las normas, principios y valores aportados por el derecho internacional de los derechos humanos- y la fuerza normativa de la Ley Fundamental, justamente dependen en buena medida de la tarea de hermenéutica constitucional, pues — como con elocuencia se ha afirmado- la interpretación constitucional «puede modificar, anular o vivificar la Constitución, o puede hacer que el sistema agonice o resplandezca» ${ }^{13}$.

Siendo así, no puede disimularse el relevante papel que están llamados a cumplir los jueces en el Estado Constitucional, quienes deben abastecer la misión de elaborar sentencias razonadas, justas y jurídicamente sustentables porque

13 CARPIZO, Jorge, voz «Interpretación constitucional», en CARBONELL, Miguel (coordinador), Diccionario de derecho constitucional, 2002, Porrúa y Universidad Nacional Autónoma de México, México, D.F., pág. 320. 
buena dosis de su legitimidad queda supeditada a la racionalidad de tales pronunciamientos.

Estrechamente conectado al Estado Constitucional, el neoconstitucionalismo (fenómeno polisémico ${ }^{14}$ que lleva a preguntarse si existe uno o varios neoconstitucionalismos), entre otras cosas, ha modificado el marco teórico del derecho constitucional, surgiendo - en cuanto a lo que aquí interesa - una nueva dogmática constitucional caracterizada por la complejización del Derecho. Éste devino menos previsible, permitiendo que en el terreno de la interpretación constitucional gane espacio la técnica de «ponderación» de valores, principios y conceptos jurídicos indeterminados, sobre la - hasta entonces- cuasi exclusiva labor de subsunción a la que los jueces estaban principalmente ceñidos.

$\mathrm{El}$ anhelable aggiornamento de la estructura de pensamiento del magistrado judicial y de su posicionamiento frente a ciertas causas dilemáticas, es tan imprescindible como dificultoso. En tal menester, la teoría de la argumentación puede proporcionar un útil servicio desde que se encarama como un elemento relevante de la interpretación constitucional, justamente porque — como subraya BARROSO- existen hipótesis (por ejemplo, ante cláusulas de contenido abierto, normas de principio y conceptos indeterminados) en las que el fundamento de legitimidad de la actuación judicial se transfiere al proceso argumentativo, pues el magistrado judicial debe demostrar racionalmente que la solución propuesta es la que realiza más adecuadamente la voluntad constitucional ${ }^{15}$.

Ciertamente entonces, converge una serie de factores que, ante la multiplicidad de fuentes jurídicas ${ }^{16}$ que aquél debe conocer y manejar fundamentalmente a partir de la citada innovación constitucional de 1994, impone un replanteamiento de su rol y lo coloca no infrecuentemente ante la exigencia de acometer una relectura de diversas cuestiones jurídicas no sólo ya a la luz de rígidos parámetros del proceso civil, sino de los postulados del derecho constitucional, el procesal constitucional y el internacional de los derechos humanos.

${ }^{14}$ Ver para ampliar, BAZÁN, Víctor, por ejemplo, en «Neoconstitucionalismo e inconstitucionalidad por omisión», Revista Brasileira de Direito Constitucional, Tema central: Teoría Constitucional do Direito, N. ${ }^{\circ}$ 7, v. 2, enero/junio de 2006, Escola Superior de Direito Constitucional, São Paulo, págs. 280/303.

15 BARROSO, Luís Roberto, «O começo da história. A nova interpretação constitucional e o papel dos princípios no direito brasileiro", en AA.VV., Visión iberoamericana del tema constitucional, Fundación Manuel García-Pelayo, Caracas, 2003, pág. 86.

16 Sobre el tema puede verse PALAZZO, Eugenio Luis, Las fuentes del derecho en el desconcierto de juristas y ciudadanos, Fundación para la Educación, la Ciencia y la Cultura, Buenos Aires, 2004. 
En esa línea se inscribe la necesidad de llevar adelante una interpretación conforme no sólo a la Constitución sino también al derecho internacional de los derechos humanos, asumiendo como realidad incuestionable la renovación del sistema de fuentes del derecho, la extensión formal y material del parámetro de control de constitucionalidad, para cuya configuración ha contribuido el incesante desarrollo del derecho internacional de los derechos humanos y la citada adjudicación de jerarquía constitucional, originaria o derivada, a un importante repertorio de instrumentos internacionales sobre aquella materia.

Paralelamente, se ha incrementado el nivel de exigencia del estándar impuesto a la magistratura judicial (esencialmente a la Corte Suprema de Justicia por su condición de cabeza de Poder y su indisimulada decisión de consolidarse definitivamente —al menos desde el ámbito material - como un tribunal constitucional ${ }^{17}$ ) en la faena de argumentación de sus sentencias, principalmente de aquellas con trascendencia constitucional, como presupuesto de su propia legitimidad institucional. Es asimismo innegable que, al demandárseles un mayor esfuerzo en la justificación racional de sus decisiones, se ven impelidos a abandonar atavismos y a recurrir a herramientas interpretativas más sofisticadas, no por esnobismo constitucional sino para reforzar el calibre de las posiciones jurisdiccionales que, en casos complejos, generen precedentes imbuidos de ejemplaridad en el marco del rol que ostentan como órganos de cierre de la justicia constitucional.

\section{LA CORTE SUPREMA DE JUSTICIA ARGENTINA Y SU JURISPRUDENCIA RECIENTE EN MATERIA DE DERECHOS HUMANOS}

\section{Los cambios recientes en la composición del Máximo Tribunal argentino}

Como relevante dato fáctico que cabe computar inicialmente, debe tomarse en consideración que en los últimos años se han producido varios movimientos

17 Para un análisis sobre esta última cuestión, ver BAZÁN, Víctor, «Algunos problemas y desafíos actuales de la jurisdicción constitucional en Iberoamérica», Anuario de Derecho Constitucional Latinoamericano 2007, T. ${ }^{\circ}$ I, Fundación Konrad Adenauer, Montevideo, págs. 37/61; y con mayor detalle, del mismo autor, «De jueces subrogantes, casos difíciles y sentencias atípicas», Jurisprudencia Argentina, LexisNexis, Buenos Aires, 15 de agosto de 2007, págs. 23/33; y «Derecho Procesal Constitucional: estado de avance, retos y prospectiva de la disciplina», La Ley [Suplemento de Derecho Constitucional], Buenos Aires, 27 de agosto de 2007, págs. 1/21. 
en la integración del Alto Tribunal. Tales innovaciones han resultado determinantes para favorecer el proceso de rediseño institucional que viene experimentando últimamente.

En el contexto anunciado, se observa que se concretaron las renuncias de los doctores Bossert y Nazareno, quienes fueron reemplazados, respectivamente, por los ministros Maqueda y Zaffaroni. Tampoco están ya los doctores López (quien falleció luego de alejarse del Tribunal) y Moliné O'Connor (removido por juicio político). Una de tales vacantes fue cubierta por la doctora Highton de Nolasco; la restante, por la doctora Argibay. Igualmente, dimitió el doctor Vázquez y se incorporó el doctor Lorenzetti (actualmente, año 2007, presidente de la Corte).

Por su parte, en junio de 2005 el doctor Belluscio renunció a su cargo con efecto a partir del $1 .^{\circ}$ de septiembre del mismo año. Días después, concretamente el 28 de este último mes, el doctor Boggiano fue destituido por el Senado de la Nación como desenlace del juicio político seguido en su contra.

En consecuencia, la Corte ha quedado integrada con los siguientes siete ministros $^{18}$ : Lorenzetti, Highton de Nolasco, Petracchi, Fayt, Maqueda, Zaffaroni y Argibay.

En el futuro, cuando se produzcan vacantes definitivas en los cargos ocupados por los actuales componentes del Tribunal, las mismas no serán cubiertas hasta que se alcance la cantidad de cinco integrantes, la que, por imperio de la Ley $26.183^{19}$, constituye el nuevo número institucional que definitivamente deberá tener el Tribunal ${ }^{20}$.

18 A la fecha de actualizar este trabajo: diciembre de 2007.

19 La ley fue sancionada el 29 de noviembre de 2006, promulgada el 15 de diciembre de 2006 y publicada en fecha 18 de diciembre de 2006.

20 El art. 2 de la citada Ley 26.183 incorpora como art. 21 del Decreto-Ley 1.285/58, texto según Ley 16.895, un precepto que en lo que aquí interesa determina que «[1]a Corte Suprema de Justicia de la Nación estará compuesta por cinco (5) jueces».

Por su parte, el art. 3 de la ley que reseñamos contiene una disposición transitoria, que reza:

«La reducción de los miembros de la Corte Suprema de Justicia de la Nación dispuesta por el artículo anterior, operará del siguiente modo:

„Desde la entrada en vigencia de la presente ley se reducirá transitoriamente a siete (7) el número de jueces que la integran. A partir de dicha reducción, las decisiones de la Corte Suprema de Justicia de la Nación se adoptarán por el voto mayoritario de cuatro (4) de sus miembros.

$» A$ posteriori, en oportunidad de producirse una vacante definitiva se reducirá transitoriamente a seis (6) el número de jueces de la Corte Suprema de Justicia de la Nación. En dicho período las decisiones de la Corte Suprema de Justicia de la Nación se adoptarán por el voto mayoritario de cuatro (4) de sus miembros.

»Producida una nueva vacante definitiva, se reducirá a cinco (5) el número de jueces que la componen. Las decisiones se adoptarán por el voto de la mayoría absoluta de sus miembros». 


\section{Explicación introductoria}

La importancia de la problemática de los derechos humanos aparece con renovado vigor en varios fallos recientes de la Corte Suprema (fundamentalmente a partir de la remozada composición del Tribunal a la que aludiéramos en el subapartado anterior), algunos de los cuales serán reseñados aquí sin perjuicio de intercalar otros en segmentos posteriores de este trabajo.

La mencionada impronta, enfocando principalmente el marco de los derechos civiles y políticos, se hace patente en: «Arancibia Clavel $»^{21}$, «Hooft ${ }^{22}$, «Verbitsky»" "Lariz Iriondo»" ${ }^{24}$, «Simón $»^{25}$, «Casal $»^{26}$, «Mazzeo» ${ }^{27}$ y «Editorial Río Negro S.A. ${ }^{28}$; donde figuran variadas referencias a la normativa y la jurisprudencia de los respectivos sistemas internacionales de protección de los derechos humanos.

Específicamente en lo que atañe a los derechos económicos, sociales y culturales, la aludida tendencia se observa, v.gr., en: "Castillo»" ${ }^{29}$, "Vizzoti ${ }^{30}$, "Aquino» ${ }^{31}$, «Milone» ${ }^{32}$, «Itzcovich» ${ }^{33}$, «Sánchez» ${ }^{34}$, «Gemelli» ${ }^{35}$, «Siri»", «Zapata ${ }^{37}$, «S., M. A.» ${ }^{38}$, «Badaro $\mathrm{I}^{39} \mathrm{y} \mathrm{II}^{40}{ }$ y Rinaldi $^{41}$.

21 «Arancibia Clavel, Enrique Lautaro s/ homicidio calificado y asociación ilícita y otros — causa N. ${ }^{\circ}$ 259—", de 24 de agosto de 2004 (Fallos, 327:3294).

22 «Hooft, Pedro Cornelio Federico c/ Buenos Aires, Provincia de s/ acción declarativa de inconstitucionalidad», de 16 de noviembre de 2004 (Fallos, 327:5118).

23 "Verbitsky, Horacio», de 3 de mayo de 2005 (Fallos, 328:1146).

24 «Lariz Iriondo, Jesús M.», de 10 de mayo de 2005 (Fallos, 328:1268).

${ }^{25}$ «Simón, Julio Héctor y otros s/ privación ilegítima de la libertad, etc. —causa N. 17.768—», de 14 de junio de 2005 (Fallos, 328:2056).

${ }^{26}$ "Casal, Matías Eugenio y otro s/ robo simple en grado de tentativa — causa N. ${ }^{\circ} 1.681$ ", de 20 de septiembre de 2005 (Fallos, 328:3399).

${ }^{27}$ «M.2333.XLII, 'Mazzeo, Julio Lilo y otros s/ recurso de casación e inconstitucionalidad'», de 13 de julio de 2007.

28 «Editorial Río Negro S.A. c/ Provincia del Neuquén s/ Acción de amparo», de 5 de septiembre de 2007.

29 "Castillo, Ángel Santos c/ Cerámica Alberdi S.A.», de 7 de septiembre de 2004 (Fallos, 327:3610).

30 "Vizzoti, Carlos Alberto c/ AMSA S.A. s/ despido», de 14 septiembre de 2004 (Fallos, 327:3677).

31 «Aquino, Isacio c/ Cargo Servicios Industriales S.A. s/ art. 39 Ley 24.557», de 21 de septiembre de 2004 (Fallos, 327:3753).

32 "Milone, Juan Antonio c/ Asociart S.A., Aseguradora de Riesgos del Trabajo s/ accidente - Ley 9.688», de 26 de octubre de 2004 (Fallos, 327:4607).

33 «Itzcovich Mabel c/ Administración Nacional de Seguridad Social (ANSeS) s/ reajustes varios», de 29 de marzo de 2005 (Fallos, 328:566).

(Notas 34 a 41 en pág. siguiente.) 
Por su parte, la trascendencia de la temática en estudio imprime igualmente su huella en algunas relevantes acordadas del Tribunal, que infra serán sumariamente relevadas.

\section{Precedentes vinculados a la materia de los derechos civiles y politicos}

En efecto, en la primera línea de decisorios mencionados el Tribunal examinó cuestiones de relevancia jurídica e institucional con facetas de singular interés en el plano de los derechos humanos, algunas de las cuales serán anunciadas en la síntesis que sigue:

\section{A) «Arancibia Clavel» y «Lariz Iriondo»}

En «Arancibia Clavel» $»^{42}$ la Corte se enfrentó a la ardua temática de la prescripción de la acción penal establecida en el ordenamiento jurídico interno vis$\grave{a}$-vis el derecho internacional consuetudinario y convencional, en el ámbito de los crímenes o delitos de lesa humanidad.

Una referencia detallada a tal fallo puede verse en BAZÁN, Víctor, «La Corte Suprema de Justicia argentina y la depuración de su competencia apelada por medio del control de constitucionalidad", Revista Iberoamericana de Derecho Procesal Constitucional, N. ${ }^{5}$, enero/junio 2006, Instituto Iberoamericano de Derecho Procesal Constitucional, Porrúa, México, D.F., págs. $257 / 287$.

34 «Sánchez, María del Carmen c/ ANSeS s/ reajustes varios», de 17 de mayo de 2005 (Fallos, 328:1602).

35 "Gemelli, Esther Noemí cl ANSeS s/ reajustes por movilidad», de 28 de julio de 2005 ( $F a$ llos, 328:2829).

36 «Siri, Ricardo Juan c/ ANSeS s/ reajustes varios», de 9 de agosto de 2005 (Fallos, 328:3045).

37 «Zapata, Lucrecia Isolina c/ ANSeS s/ pensiones», de 16 de agosto de 2005 (Fallos, 328:3099).

38 «S., M. A. c/ Siembra A.F.J.P. S.A.», de 11 de octubre de 2005 (Fallos, 328:3654).

39 «B.675.XLI, 'Badaro, Adolfo Valentín c/ ANSes s/ reajustes varios'”, de 8 de agosto de 2006 (Fallos, 329:3089).

40 Se trata de un segundo pronunciamiento en la causa identificada en la nota anterior, emitido el 26 de noviembre de 2007.

41 «R.320.XLII', 'Rinaldi, Francisco Augusto y otro c/ Guzmán Toledo, Ronal Constante y otra s/ ejecución hipotecaria'», de 15 de marzo de 2007.

42 Los votos respondieron al siguiente detalle: los doctores Zaffaroni y Highton de Nolasco suscribieron la posición mayoritaria. A su tiempo, los ministros Petracchi, Boggiano y Maqueda firmaron sendas concurrencias. Finalmente, por medio de disidencias individuales se pronunciaron los doctores Belluscio, Fayt y Vázquez. 
Concretamente, declaró procedente una queja y el recurso extraordinario que había sido denegado por la Cámara Nacional de Casación Penal, revocando la sentencia de este último tribunal, en cuanto había declarado extinguida la acción penal por prescripción en la causa seguida por el delito de asociación ilícita con fines de persecución y exterminio de opositores políticos.

Entre varios argumentos, la mayoría dejó por ejemplo sentado que el delito de asociación ilícita perpetrado para perseguir opositores políticos por medio de homicidios, desapariciones forzadas de personas y tormentos reviste carácter de crimen contra la humanidady, por ende, es imprescriptible, sin que corresponda declarar extinta la acción penal aun cuando haya transcurrido el plazo previsto en el art. 62, inc. 2. ${ }^{\circ}$, en función del art. 210 del Código Penal, pues tal disposición resulta desplazada por el derecho internacional consuetudinario y la Convención sobre la Imprescriptibilidad de los Crímenes de Guerra y de los Crímenes de Lesa Humanidad.

Además, dicho voto triunfante puntualizó (consid. 36) que a partir del fallo de la Corte Interamericana en el «Caso Velázquez Rodríguez» ${ }^{43}$, «quedó claramente establecido el deber del Estado de estructurar el aparato gubernamental, en todas sus estructuras del ejercicio del poder público, de tal manera que sus instituciones sean capaces de asegurar la vigencia de los derechos humanos, lo cual incluye el deber de prevenir, investigar y sancionar toda violación de los derechos reconocidos por la convención. Desde este punto de vista, la aplicación de las disposiciones de derecho interno sobre prescripción constituye una violación del deber del Estado de perseguir y sancionar, y consecuentemente, compromete su responsabilidad internacional (conf. CIDH, caso 'Barrios Altos', sentencia del 14 de marzo de 2001, considerando 41, Serie C N. ${ }^{\circ} 75$; caso 'Trujillo Oroza vs. Bolivia', Reparaciones, sentencia del 27 de febrero de 2002, considerando 106, Serie C N. ${ }^{\circ}$ 92; caso 'Benavides Cevallos', Cumplimiento de sentencia, resolución del 9 de septiembre de 2003, considerandos 6 y 7)».

De cualquier modo, para evitar un enfoque parcializado y aunque quebremos la línea cronológica de esta secuencia de fallos, deben señalarse algunas divergencias de criterio entre lo resuelto en «Arancibia Clavel» y lo decidido in re "Lariz Iriondo» ${ }^{44}$.

${ }_{43}$ Corte Interamericana de Derechos Humanos (en adelante, Corte IDH), sentencia de 29 de julio de 1988, Serie C, N. ${ }^{\circ}$ 4, San José de Costa Rica, consid. 172.

${ }^{44}$ Ver opinión de García Belsunce, Horacio, en la nota periodística elaborada por RouiLLoN, Jorge, «Denuncian inseguridad jurídica y hegemonía», La Nación, 10 de diciembre de 2005, Buenos Aires, pág. 2.

El entrevistado cuestionó el criterio de la Corte Suprema que consideró que «el delito de lesa humanidad sólo corresponde al terrorismo de Estado, desconociendo que el Estatuto de Roma 
En esta última, el Tribunal rechazó el recurso ordinario de apelación interpuesto por el Ministerio Público Fiscal y confirmó la sentencia de primera instancia que había desestimado el pedido de extradición realizado por España respecto de un miembro de la organización terrorista ETA en virtud de la colocación y detonación de explosivos en la vía pública.

Del consid. 26 del voto que encabeza la mayoría ${ }^{45}$ surge que "el Tribunal considera que en el derecho internacional no existe un desarrollo progresivo suficiente que permita concluir que todos y cada uno de los actos que a partir de tratados internacionales pasan a ser calificados como 'actos de terrorismo' puedan reputarse, tan sólo por esa circunstancia delitos de lesa humanidad".

Como explica Gelli, la Corte diseña una línea que divide diferentes tipos de terrorismo, algunos de los cuales - por ejemplo, cuando se trata de actos cometidos por personas asociadas ilícitamente para ello- no son delitos políticos pero tampoco de lesa humanidad ${ }^{46}$, concluyendo la mencionada autora que la cuestión jurídica luce problemática en nuestro país, «y en algún punto contradictoria con las soluciones concretas que se han articulado", por lo que, para enderezarla, se «requiere, en primer término, sincerar los parámetros de política institucional que deben resolverla ${ }^{47}$.

Puestos ambos fallos en perspectiva, y emplazando imaginariamente a los decisorios recaídos en "Simón» y "Mazzeo" —que infra abordaremos sumariamente- en la línea de "Arancibia Clavel», pareciera que la tendencia del Tribunal se dirige a generar una suerte de estándar dual: ser permeable a la reapertura de procesos en contra del denominado "terrorismo de Estado" y paralelamente refractario a adoptar idéntico criterio en causas contra lo que algunos denominan el «terrorismo subversivo» (esto último en "Lariz Iriondo»).

B) «Hooft»

En este precedente, el Tribunal admitió la tacha de inconstitucionalidad impetrada por el actor acerca de una disposición de la Ley Fundamental de la Pro-

menciona explícitamente a la política de un Estado o de una organización». En síntesis, censuró que el Tribunal entendiera que «los asesinatos, exterminios o torturas cometidos por organizaciones terroristas no estatales no son crímenes de lesa humanidad».

45 El voto triunfante fue firmado por los doctores Petracchi, Highton de Nolasco, Lorenzetti y Argibay. Por su voto, se expidieron los ministros Maqueda y Zaffaroni, conjuntamente; y Belluscio y Fayt, de manera individual. A su tiempo, la solitaria disidencia fue del doctor Boggiano.

46 Cfr. Gelli, María Angélica, «El terrorismo y el desarrollo progresivo de un delito internacional», La Ley, T. $2005-\mathrm{E}$, Buenos Aires, págs. 1179/1180.

47 Ibid., pág. 1180. 
vincia de Buenos Aires, concretamente, su art. 177, que - a juicio del accionante- le cercenaba su derecho a ser juez de Cámara —o eventualmente de Casación- al requerir, para acceder a tal cargo, «haber nacido en territorio argentino o ser hijo de ciudadano nativo si hubiese nacido en país extranjero» ${ }^{48}$.

La acción se ventiló en sede provincial y el recurso extraordinario federal planteado por el demandante contra la sentencia de la Suprema Corte de la Provincia de Buenos Aires dio lugar al pronunciamiento por el cual la Corte Suprema de Justicia de la Nación declaró que la causa en cuestión correspondía a su competencia originaria de conformidad con los arts. 116 y 117 de la C.N. Fue así como el Máximo Tribunal, por mayoría ${ }^{49}$, admitió la demanda y, argumentando la violación de los arts. 23 de la CADH y 25 del Pacto Internacional de Derechos Civiles y Políticos (PIDCP), ambos equiparados jerárquicamente a la C.N., y la consecuente discriminación sufrida por el peticionante, declaró la inconstitucionalidad del citado precepto de la Carta Magna provincial.

Como mensaje final, debe destacarse - entre variadas aristas de interés que ofrece el pronunciamiento- que el temperamento adoptado por la Corte $\mathrm{Na}$ cional trasunta su percepción en torno a la nombrada ampliación - tanto formal cuanto sustancial— del parámetro de control de constitucionalidad a partir de la innovación constitucional de 1994.

C) «Verbitsky»

El representante legal del Centro de Estudios Legales y Sociales (CELS), dedujo ante el Tribunal de Casación de la Provincia de Buenos Aires una acción de hábeas corpus correctivo y colectivo en amparo de todas las personas privadas de su libertad en jurisdicción de la Provincia de Buenos Aires detenidas en establecimientos penales y comisarías sobrepoblados, a pesar de que legal y constitucionalmente su alojamiento debería desarrollarse en centros de detención especializados.

El planteo fue desestimado por la Sala III ${ }^{a}$ de la Cámara de Casación Penal local por considerar que no era el órgano competente para intervenir en los hechos denunciados en la presentación, pues en ésta, se hacía una referencia ge-

${ }^{48}$ El actor nació en Utrecht, Holanda, el 25 abril de 1942; ingresó al país en 1948 y obtuvo la nacionalidad argentina en 1965. Además, desde 1976 hasta el momento de articular la acción, ejerció como Titular del Juzgado en lo Penal N. ${ }^{\circ} 13$ del Departamento Judicial de Mar del Plata.

${ }^{49}$ La mayoría estuvo integrada por los doctores Petracchi, Fayt, Maqueda, Zaffaroni y Highton de Nolasco. Por su parte, el único que se separó del voto triunfante fue el doctor Belluscio, quien plasmó una disidencia propiciando el rechazo de la demanda. 
nérica y colectiva a las distintas situaciones e irregularidades en que se encontraban las personas privadas de su libertad en causas penales y detenidas en comisarías o establecimientos policiales provinciales. Indicó que no procedía tomar una única decisión que englobase situaciones plurales indeterminadas, aun cuando estuvieran referidas a un problema común, y que correspondía que cada supuesto fuera evaluado por el juez propio de la causa.

Ello llevó al actor a plantear sendos recursos de nulidad e inaplicabilidad de ley, que fueron declarados inadmisibles por la Suprema Corte de Justicia provincial, frente a lo cual dedujo un recurso extraordinario, cuya denegación originó la presentación directa ante la Corte Suprema de Justicia de la Nación, que — por mayoría ${ }^{50}$ — revocó la sentencia en cuestión.

En síntesis, la Corte Nacional admitió la queja, declaró procedente el recurso extraordinario y revocó la sentencia apelada. Para operativizar el fallo, dispuso además:

- Declarar que las Reglas Mínimas para el tratamiento de Reclusos de las Naciones Unidas, recogidas por la Ley 24.660, configuran las pautas fundamentales a las que debe adecuarse toda detención;

- disponer que la Suprema Corte de Justicia de la Provincia de Buenos Aires, a través de los jueces competentes, haga cesar en el término de sesenta (60) días la detención en comisarías de la provincia de menores y enfermos;

- instruir al mencionado órgano judiciario y a los tribunales de todas las instancias de la provincia para que, en sus respectivas competencias, con la urgencia del caso, hagan cesar toda eventual situación de agravamiento de la detención que importe un trato cruel, inhumano o degradante o cualquier otro susceptible de acarrear responsabilidad internacional al Estado Federal;

- ordenar al Poder Ejecutivo de la Provincia de Buenos Aires que, por intermedio de la autoridad de ejecución de las detenciones, remita a los jueces respectivos, en el término de treinta (30) días, un informe pormenorizado, en el que consten las condiciones concretas en que se cumple la detención (características de la celda, cantidad de camas, condiciones de higiene, acceso a servicios sanitarios, etc.), a fin de que éstos puedan

50 La mayoría quedó conformada por los ministros Petracchi, Maqueda, Zaffaroni, Highton de Nolasco y Lorenzetti. Por su parte, en disidencia se expidió el doctor Boggiano y, también disidentemente — aunque sólo en forma parcial—, lo hicieron por separado los ministros Fayt y Argibay. 
ponderar adecuadamente la necesidad de mantener la detención, o bien, dispongan medidas de cautela o formas de ejecución de la pena menos lesivas. Asimismo, entendió pertinente que se informara en el plazo de cinco (5) días toda modificación relevante de la situación oportunamente comunicada;

- disponer que cada sesenta (60) días el Poder Ejecutivo de la Provincia de Buenos Aires informe a la Corte Nacional las medidas que adopte para mejorar la situación de los detenidos en todo el territorio de la provincia;

- exhortar a los Poderes Ejecutivo y Legislativo de la Provincia de Buenos Aires a adecuar su legislación procesal penal en materia de prisión preventiva y excarcelación y su legislación de ejecución penal y penitenciaria, a los estándares constitucionales e internacionales; y

- encomendar al Poder Ejecutivo de la Provincia de Buenos Aires que, a través de su Ministerio de Justicia, organice la convocatoria de una mesa de diálogo a la que invitaría a la accionante y restantes organizaciones presentadas como amici curiae, sin perjuicio de integrarla con otros sectores de la sociedad civil, debiendo informar a esta Corte cada sesenta días de los avances logrados.

El fallo es sin duda relevante, entre otros aspectos, porque la Corte - activismo mediante- diseñó un remedio jurisdiccional para combatir las omisiones contrarias a la Constitución y a los tratados internacionales con valencia homóloga en que incurren las autoridades provinciales competentes en materia de ejecución penal, y que resultan violatorias, v.gr., del art. 18 de la C.N. y de los arts. XXV de la Declaración Americana de los Derechos y Deberes del Hombre (todo individuo «tiene derecho también a un tratamiento humano durante la privación de su libertad»), 10 del PIDCP («toda persona privada de libertad será tratada humanamente y con el respeto debido a la dignidad inherente al ser humano») y 5 , inc. $2 .^{\circ}$, de la CADH (norma con similar configuración léxica y contenido semántico a la del Pacto citado en último término) — ver consid. 39 de la mayoría-.

En el sentido expuesto, el Tribunal eleva al nivel de estándar básico infranqueable a las «Reglas Mínimas para el tratamiento de Reclusos de las Naciones Unidas", recogidas por la Ley 24.660, como cartabón de pautas fundamentales a las que debe sujetarse toda detención para que la privación de la libertad ambulatoria legítimamente impuesta por un órgano judicial competente se adapte a los lineamientos indispensables para preservar la dignidad de la persona humana (cfr. id. consid.). 
D) «Simón»

En el presente caso ${ }^{51}$ el Tribunal afrontó el complejo tema del análisis de constitucionalidad de las Leyes 23.492 de "punto final» y 23.521 de «obediencia debida», a las que declaró inconstitucionales. Al mismo tiempo, determinó a todo evento de ningún efecto, además de dichas leyes, a cualquier acto fundado en ellas que pudiera oponerse al avance de los procesos que se instruyan, o al juzgamiento y eventual condena de los responsables, u obstaculizar en forma alguna las investigaciones llevadas a cabo por los canales procedentes y en el ámbito de sus respectivas competencias, por crímenes de lesa humanidad cometidos en el territorio de la Nación argentina.

Presentado en breves líneas, se observa que en el consid. 23 de la moción triunfante la Corte Suprema puntualizó que las dudas con respecto al alcance concreto del deber del Estado argentino con relación a aquellas leyes habían quedado esclarecidas a partir de la decisión de la Corte Interamericana en el caso «Barrios Altos» ${ }^{52}$, que mencionáramos precedentemente. Y para enfatizar la posición que adoptaba, en el consid. siguiente dejó en claro que la traslación de las conclusiones de "Barrios Altos» al caso argentino "resulta imperativa», si es que las decisiones de la Corte Interamericana «han de ser interpretadas de buena fe como pautas jurisprudenciales», al tiempo de subrayar (en el consid. 26) que en aquel caso ésta «estableció severos límites a la facultad del Congreso para amnistiar, que le impiden incluir hechos como los alcanzados por las leyes de punto final y obediencia debida. Del mismo modo, toda regulación de derecho interno que, invocando razones de 'pacificación' disponga el otorgamiento de cualquier forma de amnistía que deje impunes violaciones graves a los derechos humanos perpetradas por el régimen al que la disposición beneficia, es contraria a claras y obligatorias disposiciones de derecho internacional, y debe ser efectivamente suprimida».

51 El esquema de votación fue el siguiente: la moción que encabeza el fallo fue firmada por el doctor Petracchi. Por su parte, en sendas concurrencias se pronunciaron los ministros Maqueda, Zaffaroni, Highton de Nolasco, Lorenzetti (los cuatro coinciden con los consids. 1 a 11 del voto del doctor Petracchi), Argibay (quien concuerda con los consids. 1 a 6 del mencionado voto del ministro Petracchi) y Boggiano. Finalmente, el doctor Fayt se expidió en disidencia.

${ }^{52} \mathrm{La}$ referencia completa es la siguiente: Corte IDH, "Caso Barrios Altos, Chumbipuma Aguirre y otros vs. Perú», sentencia de 14 de marzo de 2001, Serie C, N. ${ }^{\circ}$ 75, San José de Costa Rica. 
E) «Casal»

En orden a garantizar el derecho a la doble instancia del condenado en un juicio oral adecuándolo a las exigencias de la CADH (art. 8.2.'h') y el PIDCP (art. 14.5), la Corte ${ }^{53}$ determinó que la Cámara Nacional de Casación Penal no será en adelante una instancia extraordinaria sino que actuará como instancia ordinaria, es decir, deberá realizar una revisión amplia del caso (de acuerdo con el art. 456 del Código Procesal Penal de la Nación), con lo cual no podrá limitarse a examinar sólo cuestiones jurídicas, sino también los hechos expuestos y las pruebas rendidas en el juicio oral.

El consid. 23 del voto mayoritario indica que el aludido precepto del citado Código debe ser leído exegéticamente proporcionando un resultado análogo al de la doctrina y la jurisprudencia alemanas con la teoría de la Leistungsfähigkeit, o sea, que el tribunal de casación debe agotar el esfuerzo por revisar todo lo que pueda revisar, es decir, por agotar la revisión de lo revisable.

Dicho de otra manera, la Corte interpreta tal norma de acuerdo con la teoría del máximo de rendimiento (ver consid. 32 de la mayoría), debiendo la tarea revisora ser todo lo extensa que sea posible conforme a las posibilidades y constancias de cada caso particular y sin magnificar las cuestiones reservadas a la inmediación, sólo evitables por imperio de la oralidad conforme a la naturaleza de las cosas (consid. 34 de la moción triunfante) ${ }^{54}$.

\section{F) «Mazzeo»}

Se trata de un pronunciamiento que exuda gran importancia institucional y un firme mensaje de la Corte Suprema como cabeza de unos de los poderes del Estado, en este caso, al Ejecutivo.

Por mayoría ${ }^{55}$, confirmó la sentencia de la Sala II. a de la Cámara Nacional de Casación Penal que había reputado inconstitucional el Decreto 1.002/89 mediante el cual el Poder Ejecutivo Nacional indultó - entre otras personas- a Santiago Omar Riveros en la ex causa 85 de la Cámara Federal de Apelaciones

53 La mayoría estuvo compuesta por los doctores Petracchi, Maqueda, Zaffaroni y Lorenzetti. Por su parte, en votos concurrentes lo hicieron los ministros Highton de Nolasco, Fayt y Argibay.

54 Tal posición ha sido reiterada por la Corte en «Martínez Areco, Ernesto s/ causa N. ${ }^{\circ} 3.792$, recurso de casación (interpretación del art. 456, inc. 2. , del Código Procesal Penal de la Nación)», de 25 de octubre de 2005 (Fallos, 328:3741).

55 Los alineamientos fueron: por la mayoría, votaron los doctores Lorenzetti, Highton de Nolasco, Maqueda y Zaffaroni; en disidencia se expidió el ministro Fayt y en disidencia parcial lo hizo la doctora Argibay. 
de San Martín. El Máximo Tribunal basó la declaración de inconstitucionalidad del mencionado decreto, en los arts. $18,31,75-$ inc. $22-, 99-$ inc. $5 .^{\circ}-\mathrm{y}$ 118 de la C.N.; 1, 8.4 y 25 de la CADH; y 14.7 del PIDCP (consid. 38 del voto que encabeza el decisorio). Naturalmente, la interpretación realizada por la mayoría de la Corte moldea un relevante criterio institucional (que seguramente no agotará su operatividad con el presente caso) en torno a la invalidez constitucional de la atribución presidencial de emitir indultos que beneficien a sujetos acusados de cometer delitos de lesa humanidad (ver, por ejemplo, consid. 31 de la mayoría).

Es particularmente relevante el consid. 21 de la mayoría en el que, mostrando gran permeabilidad hacia los pronunciamientos de la Corte Interamericana de Derechos Humanos, cita el criterio que ésta expusiera en el caso «Almonacid Arellano" "56, de 26 de septiembre de 2006, en los siguientes términos: «La Corte es consciente que los jueces y tribunales internos están sujetos al imperio de la ley y, por ello, están obligados a aplicar las disposiciones vigentes en el ordenamiento jurídico. Pero cuando un Estado ha ratificado un tratado internacional como la Convención Americana, sus jueces, como parte del aparato del Estado, también están sometidos a ella, lo que les obliga a velar porque los efectos de las disposiciones de la Convención no se vean mermadas por la aplicación de leyes contrarias a su objeto y fin, y que desde un inicio carecen de efectos jurídicos. En otras palabras, el Poder Judicial debe ejercer una especie de 'control de convencionalidad' entre las normas jurídicas internas que aplican en los casos concretos y la Convención Americana sobre Derechos Humanos. En esta tarea, el Poder Judicial debe tener en cuenta no solamente el tratado, sino también la interpretación que del mismo ha hecho la Corte Interamericana, intérprete última de la Convención Americana» (párr. 124).

Recapitulando, pone en cabeza de los poderes judiciales de los Estados la obligación de llevar adelante el 'control de convencionalidad' entre las normas jurídicas internas que aplican en los casos concretos y la $\mathrm{CADH}$, tomando en consideración al efecto no sólo la letra de dicho pacto sino la lectura que del mismo ha realizado el Tribunal interamericano que, como se sabe, es el intérprete último de aquél.

En definitiva, entroniza la pauta de interpretación conforme a la $C A D H$ como estándar hermenéutico a respetar y resguardar por parte de los órganos jurisdiccionales vernáculos.

56 Corte IDH, «Caso Almonacid Arellano y otros vs. Chile», sentencia sobre excepciones preliminares, fondo, reparaciones y costas, 26 de septiembre de 2006, Serie C, N. ${ }^{\circ} 154$, San José de Costa Rica. 
Por lo demás, el fallo genera una controversia jurisdiccional entre los miembros de la Corte Suprema (ver las respectivas disidencias de los jueces Fayt y Argibay) y doctrinal en torno a la declaración de inconstitucionalidad de los decretos de indulto en delitos de lesa humanidad y las garantías de la cosa juzgada $\mathrm{y}$ de ne bis in idem.

Si bien son entendibles y fundados los argumentos de quienes privilegian estas garantías constitucionales y critican la decisión de la mayoría, tanto el tenor jurídico y axiológico de los crímenes de lesa humanidad, cuanto la impronta de la reforma constitucional de 1994 en materia de derechos humanos y el hecho insoslayable de la asunción por nuestro país de compromisos internacionales en materia de derechos humanos ${ }^{57}$, agravados por la jerarquización constitucional de diversos instrumentos en la materia y el reconocimiento de la competencia de órganos gravitantes en el sistema interamericano (Comisión y Corte Interamericanas ${ }^{58}$ ); son circunstancias no fácilmente desdeñables que a

57 Una muestra reciente de la tendencia seguida por Argentina en materia de derechos humanos se configuró el 14 de diciembre de 2007, cuando procedió a ratificar la Convención Internacional para la Protección de Todas las Personas contra las Desapariciones Forzadas, depositando el respectivo instrumento ratificatorio en la sede de las Naciones Unidas, en Nueva York. Nuestro país, que aprobó la Convención por medio de la Ley 26.298, se convirtió en el primero de América y el segundo en el mundo en ratificar dicha Convención, que fue firmada por 71 Estados y que requiere de 20 ratificaciones para entrar en vigor internacionalmente.

Según explica la Cancillería argentina, "[u]na de sus disposiciones más trascendentes es aquella que consagra la jurisdicción universal para garantizar la obligación de todo Estado Parte de investigar, detener y eventualmente juzgar a toda persona que se encuentre en su territorio, de la que se supone que ha cometido este delito, o de ser el caso a extraditarla, sin que se pueda considerar la desaparición como delito político para rechazar los pedidos de extradición». Añade que viene a llenar "un vacío existente en el derecho internacional tanto en términos de prevención de las violaciones de derechos humanos y de los derechos de las víctimas, así como en cuanto a la obligación de los Estados de investigar y sancionar a los responsables» (cfr. "Derechos Humanos: La Argentina se convirtió hoy en el primer país de América en ratificar la Convención contra las Desapariciones Forzadas", Información para la Prensa N. ${ }^{\circ}$ 519/07, 14 de diciembre de 2007, Ministerio de Relaciones Exteriores, Comercio Internacional y Culto, Fuente: www.cancilleria.gov.ar/portal/prensa).

58 No puede soslayarse que la Corte Interamericana dijo en «Barrios Altos» que «son inadmisibles las disposiciones de amnistía, las disposiciones de prescripción y el establecimiento de excluyentes de responsabilidad que pretendan impedir la investigación y sanción de los responsables de las violaciones graves de los derechos humanos tales como la tortura, las ejecuciones sumarias, extralegales o arbitrarias y las desapariciones forzadas, todas ellas prohibidas por contravenir derechos inderogables reconocidos por el Derecho Internacional de los Derechos Humanos» (sentencia de 14 de marzo de 2001, párr. 41).

Además, en el citado caso "Almonacid Arellano" reiteró que los Estados no pueden sustraerse del deber de investigar, determinar y sancionar a los responsables de los crímenes de lesa hu- 
nuestro criterio justifican la posición sustentada por la mayoría del Máximo Tribunal argentino.

Sin embargo, y como toda cuestión dilemática, naturalmente el debate seguirá abierto a su respecto.

\section{G) «Editorial Río Negro S.A.»}

Se trata de un fallo que también ostenta importancia institucional, resuelto en competencia originaria por la Corte Suprema para preservar la libertad de expresión y reiterar su enorme relevancia en un Estado democrático y republicano.

La demanda (acción de amparo) se sustentaba en la disminución y posterior cesación de publicidad oficial en el Diario Río Negro por parte del gobierno de la provincia del Neuquén. La actora atribuía tal actitud gubernamental (catalogada de "discriminatoria») a que en diciembre de 2002 el diario difundió la denuncia que el día 7 de ese mes y ese año un diputado de la provincia del Neuquén había efectuado en el sentido de que el vicepresidente primero de la Legislatura local le habría ofrecido un crédito por $\$ 640.000$ de una entidad local a fin de que diera quórum para permitir el tratamiento de las ternas propuestas por el gobernador de la provincia para cubrir las vacantes judiciales que existían en el Superior Tribunal de Justicia local "con abogados de su confianza».

En este breve repaso no podemos ahondar en la cuestión, por lo que simplemente referiremos de manera esquemática algunos puntos que hacen al criterio elaborado por la mayoría $a^{59}$ del Tribunal: a) medió supresión y reducción sustancial de la publicación oficial al diario demandante; b) no hubo motivos razonables para ello, dejándose sentado que la existencia de los mismos debe ser probada por el Estado; c) se configuró un ejercicio irrazonable de facultades discrecionales; y d) si bien no puede afirmarse la existencia de un derecho de los medios a recibir una determinada cantidad de publicidad oficial, sí existe un derecho contra la asignación arbitraria o la violación indirecta de la libertad de prensa por medios económicos.

Con relación a esto último, la Corte argumentó que el Estado puede dar o no dar publicidad oficial, pero si decide hacerlo debe cumplir dos requisitos constitucionales: a) no puede manipularla, dándola y retirándola a algunos me-

manidad aplicando leyes de amnistía u otro tipo de normativa interna; por lo que, consecuentemente, los crímenes de lesa humanidad son delitos por los que no se puede conceder amnistía (párr. 114).

59 Conformaron la mayoría los doctores Lorenzetti, Highton de Nolasco y Zaffaroni; votando concurrentemente con ellos el ministro Fayt. Por su parte, las disidencias correspondieron en forma individual al doctor Maqueda y conjunta a los ministros Petracchi y Argibay. 
dios en base a criterios discriminatorios; y b) no puede utilizarla como un modo indirecto de afectar la libertad de expresión.

Por lo demás, confirma que es un deber de los tribunales proteger los medios para que exista un debate plural sobre los asuntos públicos, lo que constituye un presupuesto esencial para el gobierno democrático. Asimismo, se remite a ciertas pautas sentadas por la Corte Interamericana de Derechos Humanos en la OC-5/85 sobre «La colegiación obligatoria de periodistas» ${ }^{60}$ y en las sentencias recaídas en los casos «La Última Tentación de Cristo [Olmedo Bustos y otros] c/ Chile» ${ }^{61}$ (5 de febrero de 2001), «Ivcher Bronstein c/ Perú» ${ }^{62}$ (6 de febrero de 2001) y "Herrera Ulloa c/ Costa Rica» ${ }^{63}$ (2 de julio de 2004), para concluir reafirmando que la libertad de expresión tiene una dimensión individual y una dimensión social, y que dicha libertad requiere, por un lado, que nadie sea arbitrariamente menoscabado o impedido de manifestar su propio pensamiento y representa, por tanto, un derecho de cada individuo; pero implica también, por otro lado, un derecho colectivo a recibir cualquier información y a conocer la expresión del pensamiento ajeno.

En síntesis, admitió la demanda condenando a la Provincia del Neuquén a que las futuras publicaciones sean adjudicadas con un criterio compatible con las razones expuestas; no obstante lo cual, entendió que las modalidades de ejecución deberían diferir necesariamente de las usuales, por lo que en función de tales condiciones, requirió a la demandada la presentación en un plazo de treinta días de un esquema de distribución de publicidad, respetuoso de los términos y principios que informan la decisión que el Tribunal adoptó.

\section{Linea jurisprudencial relativa a derechos económicos, sociales y culturales}

En cuanto a lo que atañe a los derechos económicos, sociales y culturales ${ }^{64}$, es importante colacionar aunque sea telegráficamente, los fallos enumerados supra, según los siguientes trazos referenciales:

${ }^{60}$ Corte IDH, OC-5/85, de 13 de noviembre de 1985, «La colegiación obligatoria de periodistas [arts. 13 y 29 Convención Americana sobre Derechos Humanos]», Serie A: Fallos y Opiniones, N. ${ }^{\circ}$, Secretaría de la Corte Interamericana de Derechos Humanos, San José de Costa Rica, 1985, específicamente el párr. 69.

${ }^{61}$ Corte IDH, Serie C, N. ${ }^{\circ} 73$, párr. 65.

${ }^{62}$ Corte IDH, Serie C, N. ${ }^{\circ}$ 74, párr. 149.

${ }^{63}$ Corte IDH, Serie C, N. ${ }^{\circ}$ 107, párr. 108.

${ }^{64}$ Sobre los derechos económicos, sociales y culturales, ver Bazán, Víctor, entre otros trabajos, en: "Vías de maximización protectiva de los derechos económicos, sociales y culturales», La 
A) «Castillo»

Con criterio unánime de los ministros votantes ${ }^{65}$, el Tribunal declaró la inconstitucionalidad del art. 46.1 de la Ley de Riesgos del Trabajo (LRT) 24.557, que establece la competencia federal para recurrir las resoluciones de las comisiones médicas provinciales, norma que el Tribunal juzgó contraria a la pauta consagrada en los arts. 75, inc. 12, y 116 de la C.N., en función de la cual los temas de derecho laboral y seguridad social son de competencia de los fueros ordinarios.

\section{B) «Vizzoti»}

Modificando su posición jurisdiccional anterior, unánimemente ${ }^{66}$ declaró inconstitucional, por irrazonable, el límite a la base salarial previsto en los párrafos $2 .^{\circ}$ y $3 .^{\circ}$ del art. 245 de la Ley de Contrato de Trabajo (según Ley 24.01367) para calcular la indemnización por despido incausado.

Por lo demás, y con un movimiento activista adicional, al tiempo de desactivar por inconstitucional aquel límite, moduló un criterio normativo aplicable a la causa al determinar per se que correspondía aplicar aquella limitación sólo hasta el 33\% de la mejor remuneración mensual, normal y habitual computable.

C) «Aquino»

En este fallo confirmó - mayoritariamente ${ }^{68}$ - las sentencias de las instancias de mérito en las que, en el contexto de un reclamo por accidente de trabajo, se había declarado la inconstitucionalidad del art. 39.1 de la LRT y conde-

Ley, 30 de julio de 2007, Buenos Aires, págs. 1/6; «Los derechos económicos, sociales y culturales en acción: sus perspectivas protectorias en los ámbitos interno e interamericano», Anuario de Derecho Constitucional Latinoamericano 2005, Fundación Konrad Adenauer, Montevideo, págs. 547/583; e «Impacto de la reforma constitucional en el ámbito de los derechos económicos, sociales y culturales», Jurisprudencia Argentina, Número Especial 'A 10 años de la reforma constitucional', LexisNexis, 25 de agosto de 2004, Buenos Aires, págs. 12/29.

${ }^{65}$ Votaron los doctores Petracchi, Belluscio, Fayt, Boggiano, Maqueda, Zaffaroni y Highton de Nolasco.

${ }^{66}$ En efecto, votaron coincidentemente todos los ministros firmantes, doctores Petracchi, Belluscio, Fayt, Boggiano, Maqueda, Zaffaroni y Highton de Nolasco.

${ }^{67}$ B.O. de 17 de diciembre de 1991.

${ }^{68}$ La posición triunfante fue sustentada por los doctores Petracchi y Zaffaroni. A su turno, por su voto se pronunciaron los ministros Belluscio y Maqueda, en concurrencia conjunta, y Highton de Nolasco y Boggiano, en mociones individuales. 
nado a la empleadora al pago de la indemnización por daños fundada en el Código Civil.

D) «Milone»

Por mayoría ${ }^{69}$, entendió que si bien la LRT (art. 14.2.'b') no resulta inconstitucional por establecer como regla, para determinadas incapacidades, que la reparación dineraria por el infortunio laboral sea satisfecha mediante una renta periódica, sí es merecedora de reproche constitucional por no fijar excepción alguna (que permita que la reparación pueda ser saldada en un pago único) para supuestos como el analizado en la causa: persona de 55 años, cuya actividad laboral consistía en conducir un taxi y que, entre los distintos padecimientos detectados que le generaban una minusvalía laboral del 65\%, había perdido la visión del ojo izquierdo, configurándose una situación que le imposibilitaba su reubicación laboral dado el tipo de tarea que realizaba.

En tal sentido, el Tribunal concluyó, por tanto, que el criterio legal no se adecuaba al objetivo reparador cuya realización procuraba, añadiendo que frente a tales circunstancias la norma consagraba una solución incompatible con el principio protectorio y los requerimientos de condiciones equitativas de labor (art. 14 bis de la Ley Fundamental), al tiempo que mortificaba el ámbito de libertad resultante de la autonomía del sujeto para elaborar su proyecto de vida e introducía un trato discriminatorio.

E) «Itzcovich»

Declaró aquí por mayoría ${ }^{70}$ la invalidez constitucional del art. 19 de la Ley 24.463 — de «solidaridad previsional»—, que habilitaba un recurso ordinario de apelación ante aquélla respecto de las sentencias definitivas de la Cámara Federal de la Seguridad Social.

En breves palabras, el Tribunal recordó la imposibilidad de pronunciarse sobre el acierto o la conveniencia de las soluciones legislativas, dejó en claro que la experiencia recogida durante los casi diez años de vigencia de la Ley

69 Formaron la mayoría los doctores Petracchi, Boggiano, Maqueda, Zaffaroni y Highton de Nolasco. En disidencia conjunta votaron los ministros Belluscio y Fayt.

${ }^{70} \mathrm{El}$ voto que encabeza la sentencia fue suscripto por los ministros Petracchi, Fayt y Highton de Nolasco. Por su parte, y según sus votos, se expidieron los doctores Maqueda y Zaffaroni, en forma conjunta, y Lorenzetti, de manera individual (todos éstos, concurrentemente con la decisión mayoritaria). Finalmente, en sendas disidencias parciales, se pronunciaron los jueces Belluscio, Boggiano y Argibay. 
$24.463^{71}$ la hacía susceptible de reproche con base constitucional por resultar irrazonable, en tanto el medio que arbitraba no era adecuado a los fines cuya realización procuraba o porque consagraba una manifiesta iniquidad (consid. 5. ${ }^{\circ}$ de la mayoría); recordando también que el principio de razonabilidad exige que deba cuidarse especialmente que los preceptos mantengan coherencia con las reglas constitucionales durante todo el lapso que dure su vigencia, de suerte que su aplicación no resulte contradictoria con lo establecido por la C.N. (consid. 10, in fine, de la moción triunfante). Como subraya GELLI, en el decisorio se utilizaron varias pautas de control de razonabilidad, entre ellas, la de la inconstitucionalidad sobreviniente y una versión morigerada de ésta, la de la adaptabilidad, llevando el control, incluso, hasta el análisis de la racionalidad de la categoría de diferenciación en materia de igualdad ${ }^{72}$.

A ello se sumaron las apreciaciones del voto mayoritario en función de las cuales estimó que «el procedimiento previsional se vincula con personas que, por lo general, han concluido su vida laboral y, en la mayoría de los casos, han supeditado su sustento a la efectiva percepción de los haberes que les corresponden por mandato constitucional» (consid. 11) y que el "fin protector de las prestaciones comprometidas justifica adoptar el criterio que más convenga a la celeridad del juicio, siempre y cuando las partes hayan tenido la oportunidad de ser oídas con arreglo a las reglas del debido proceso, recaudos que se encuentran asegurados por la existencia de tribunales especializados y la doble instancia» (id. consid.) —en todos los casos las bastardillas son nuestras-.

Por tal vía argumental concluyó que el art. 19 de la Ley 24.463 carecía, al momento de fallar, de la racionalidad exigida por la Ley Fundamental y por ello debia declarar su invalidez (consid. 13); entendiendo asimismo que dicha solución se avenía también con la necesidad de simplificar y poner límites temporales a la decisión final en las controversias de índole previsional (cfr. doctrina de Fallos, 298:312, 302:299, 311:1644, 319:2151), respetando así los principios que resultan de convenciones internacionales que tienen reconocimiento constitucional (art. 25 de la Convención Americana sobre Derechos Humanos y Corte Interamericana, "Caso Las Palmeras», sentencia del 6 de diciembre de 2001, Serie $\mathrm{C}, \mathrm{N} .^{\circ} 90$, párrafo 58 y posteriores) — consid. 14 -

Por último, es de hacer notar que pocos días después de fallado el caso «Itzcovich», el Congreso de la Nación sancionó la Ley $26.025^{73}$ por medio de la

${ }^{71}$ Recuérdese que fue publicada el 30 de marzo de 1995.

72 Gelli, María Angélica, «El caso 'Itzcovich'. ¿Un fallo institucional de la Corte Suprema?», La Ley, 11 de abril de 2005, Buenos Aires, pág. 1.

${ }^{73}$ B.O. de 22 de abril de 2005. 
cual derogó el aludido art. 19 de la Ley 24.463, es decir, el que fuera declarado inconstitucional por el pronunciamiento en cuestión. Naturalmente, éste aceleró los tiempos e indujo el nacimiento en sede parlamentaria de semejante respuesta legislativa, consistente con el temperamento premoldeado judicialmente.

\section{F) «Sánchez»}

Se pronunció - por mayoría $a^{74}$ - a favor de la movilidad de los haberes previsionales (en el caso, de una pensión) de conformidad con las variaciones registradas en el índice del nivel general de remuneraciones ${ }^{75}$.

$\mathrm{Al}$ respecto, y si bien no se agota la polémica ni se brinda respuesta a todos los interrogantes en torno de la problemática de la seguridad social, al menos da

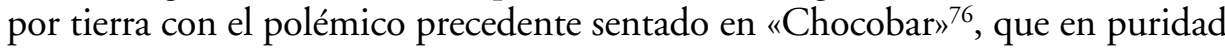
"congeló» la movilidad prestacional consagrada en el art. 14 bis, párr. 3. ${ }^{\circ}$, de la Carta Magna.

${ }^{74}$ La mayoría quedó constituida con los doctores Petracchi, Belluscio, Fayt, Highton de Nolasco y Lorenzetti. A su turno, concurrentemente votaron los ministros Zaffaroni y Argibay, de modo conjunto, y Maqueda, individualmente. Por último, en disidencia se expidió el doctor Boggiano.

75 Es útil destacar que en la causa «Andino, Basilio Modesto c/ ANSeS s/ reajustes varios», de 9 de agosto de 2005 (Fallos, 328:3041), ante el planteo de «hecho nuevo» y la solicitud de que se aplique la solución dispuesta en «Sánchez», la Corte rechazó la pretensión sustentándose en la imposibilidad de invocar ante ella hechos nuevos (art. 280, último apartado, del Código Procesal Civil y Comercial de la Nación) y en las propias constancias de la causa ya que, según afirmó, además de la prohibición legal expuesta, la propia parte había requerido al demandar la aplicación del precedente «Chocobar» (ver nota siguiente) para obtener el reajuste de la prestación en el lapso posterior al 31 de marzo de 1991 y consentido el fallo de primera instancia que así lo había resuelto. Debe recordarse que la mayoría estuvo integrada por los doctores Petracchi, Belluscio, Fayt, Zaffaroni y Lorenzetti; mientras que, concurrente y conjuntamente, se pronunciaron los ministros Maqueda, Highton de Nolasco y Argibay.

Tangencialmente, y para compulsar un interesante análisis en torno a la inconveniencia de efectuar una «hermenéutica mutativa o irrazonable» de la resolución de la Corte Suprema en "Andino», es recomendable leer el voto minoritario que integra la resolución de la Sala II. a de la Cámara Federal de la Seguridad Social en la causa «Ibáñez, Máximo cl ANSeS s/ reajustes varios», de 20 de septiembre de 2005. En el caso, la moción en minoría propiciaba aplicar lo decidido por la Corte Suprema en «Sánchez» en cuanto al cálculo de la movilidad previsional, aun cuando técnicamente el actor no había articulado recurso de apelación contra la sentencia de primera instancia que dispuso que dicho reajuste se fijara con arreglo al precedente "Chocobar» del Máximo Tribunal. Un comentario al pronunciamiento de la Cámara Federal de la Seguridad Social recaído en «Ibáñez», puede leerse en BAZÁN, Víctor, «Dos visiones del derecho ante un reclamo previsional», La Ley, T. ${ }^{\circ}$ 2006-B, Buenos Aires, págs. 605/614.

76 Fallos, 319:3241, de 27 de diciembre de 1996. 
Entre otras consideraciones de interés, en el consid. $3 .^{\circ}$ del voto mayoritario, se preocupó en aclarar que ratificaba «los principios básicos de interpretación sentados acerca de la naturaleza sustitutiva que tienen las prestaciones previsionales y rechaza toda inteligencia restrictiva de la obligación que impone al Estado otorgar 'jubilaciones y pensiones móviles', según el art. 14 bis de la Constitución Nacional y los fines tuitivos que persiguen las leyes reglamentarias en esta materia. Los tratados internacionales vigentes, lejos de limitar o condicionar dichos principios, obligan a adoptar todas las medidas necesarias para asegurar el progreso y plena efectividad de los derechos humanos, compromiso que debe ser inscripto, además, dentro de las amplias facultades legislativas otorgadas por el art. 75, inc. 23, de la Ley Fundamental, reformada en 1994, con el fin de promover mediante acciones positivas el ejercicio y goce de los derechos fundamentales reconocidos, en particular, a los ancianos».

\section{G) «Gemelli»}

El Tribunal confirmó por unanimidad ${ }^{77}$ la sentencia de la Sala I. ${ }^{a}$ de la Cámara Federal de la Seguridad Social que había reconocido el derecho de la actora a que sus haberes jubilatorios se ajustaran de acuerdo con las disposiciones de la Ley 24.016, que establece un estatuto especial y autónomo para los docentes.

Sostuvo que la Ley 24.241 (sistema integrado de jubilaciones y pensiones) no contiene cláusula alguna que modifique o extinga a la mencionada Ley 24.016, sin que resulte apropiada la invocación de los arts. $129^{78}$ y $168^{79}$ de aquella ley, y que tampoco podía admitirse la alegación de la apelante (Administración $\mathrm{Na}$ cional de Seguridad Social — ANSeS-) en punto a que se habría producido la derogación tácita de la normativa en cuestión ya que el art. 191 de la Ley 24.241 prevé que a los efectos de la interpretación de esta normativa, «debe estarse a lo siguiente: a) Las normas que no fueran expresamente derogadas mantienen su plena vigencia», además de que no basta para desvirtuar dicha conclusión la mención del Decreto 78/94, que con el pretexto de reglamentar el art. 168 de la Ley 24.241 dispuso la derogación, entre otras, de la Ley 24.016, pues fue declarado

77 Votaron los doctores Petracchi, Belluscio, Fayt, Maqueda, Zaffaroni, Highton de Nolasco, Lorenzetti y Argibay.

${ }_{78}$ Norma que establece el tiempo y el modo de la entrada en vigor del sistema integrado de jubilaciones y pensiones.

79 Precepto que se refiere a la pérdida de vigencia de las Leyes 18.037 y 18.038 , sus modificatorias y complementarias, entre las que no cabe incluir a la Ley 24.016 por tratarse de un estatuto especial y autónomo para los docentes, que sólo remite a las disposiciones del régimen general en las cuestiones no regladas por su texto (art. 2). 
inconstitucional por el Tribunal en «Craviotto, Gerardo Adolfo y otros c/ Poder Ejecutivo Nacional - Ministerio de Justicia de la Nación» ${ }^{80}$.

En definitiva, concluyó que el régimen jubilatorio de la Ley 24.016 ha quedado sustraído de las disposiciones que integran el sistema general reglamentado por las Leyes 24.241 y 24.463, con el que coexiste, manteniéndose vigente con todas sus características, entre las que se encuentra su pauta de movilidad; por lo tanto, y en función del art. 4 de la Ley 24.016 el haber jubilatorio del personal docente sería equivalente al $82 \%$ móvil de la remuneración mensual, porcentaje que el Estado debe asegurar, con los fondos que concurran al pago, cualquiera que sea su origen, y sólo por excepción y por el lapso de cinco años - a partir de la promulgación de la ley- los montos móviles debían ser del 70\%.

\section{H) «Siri»}

Tomando como antecedente lo resuelto en "Gemelli», la Corte determinó también unánimemente ${ }^{81}$ - la movilidad de las jubilaciones del actor, $e x$ funcionario superior del Servicio Exterior de la Nación. Al respecto sostuvo que los beneficios establecidos para estos últimos quedaron sustraídos de las Leyes 24.241 y 24.463 , conservando la movilidad propia de la Ley 22.731 (régimen previsional para funcionarios del mencionado Servicio Exterior), por constituir un estatuto específico y autónomo que sólo remite a las normas generales que rigen a los agentes de la Administración Pública en las cuestiones no modificadas por su texto (cfr. art. 2 de la Ley 22.731 y art. 1 de la Ley $24.019^{82}$ ).

\section{I) «Zapata»}

La Corte revocó — por mayoría ${ }^{83}$ — la sentencia de la Sala II. ${ }^{a}$ de la Cámara Federal de la Seguridad Social que había rechazado la solicitud de pensión for-

${ }^{80}$ Fallos, 322:752, de 19 de mayo de 1999.

81 Suscribieron la sentencia los ministros Petracchi, Belluscio, Fayt, Maqueda, Zaffaroni, Highton de Nolasco, Lorenzetti y Argibay.

82 Debe destacarse que el accionante había obtenido la jubilación ordinaria según la aludida Ley 22.731, que asegura el derecho a percibir los haberes mensuales de acuerdo con una proporción del sueldo asignado al cargo de mayor jerarquía ejercido en actividad. Además, aquella normativa fue reafirmada por el art. 1 de la Ley 24.019, con la única excepción de que los montos móviles de los beneficios debían ser del $70 \%$ por el lapso de cinco años a partir de su promulgación (cfr. su art. 2).

${ }^{83}$ Mayoría integrada por los doctores Petracchi, Belluscio, Fayt, Maqueda y Lorenzetti. Concurrentemente, se manifestaron los ministros Zaffaroni y Highton de Nolasco, de modo conjunto, y Argibay, de manera individual. 
mulada por la actora por la muerte de su marido, argumentando - para sustentar la denegatoria - que el matrimonio celebrado por ésta en el extranjero carecía de validez en Argentina, ya que se había vuelto a casar sin tener aptitud nupcial.

Separándose de tal fundamento, el Máximo Tribunal reconoció el derecho al beneficio de pensión solicitado por la actora, quien se había separado de su primer marido por el art. 67 bis de la Ley 2.393 y posteriormente contrajo nuevas nupcias en Uruguay en 1972.

En síntesis, reivindicó el carácter tutelar del derecho previsional y dejó en claro que, frente a la recepción por el derecho matrimonial argentino del principio de disolubilidad del matrimonio por divorcio por medio de la Ley 23.515 y atento al criterio de actualidad con que debía apreciarse el orden público internacional, el ordenamiento jurídico argentino carecía, precisamente, de interés actual en reaccionar ante un matrimonio celebrado en el extranjero mediando entonces impedimento de ligamen ${ }^{84}$. Asimismo, manifestó que, al haberse probado diecisiete años de la unión matrimonial, sumado a que fue el causante quien provocó la ruptura de la convivencia y tuvo que ser excluido del hogar por su comportamiento violento, además de haber sido condenado a proporcionar alimentos a sus hijos, resultaba procedente la demanda tendiente a obtener el beneficio de pensión derivado de la jubilación de aquél (cfr. art. 53 de la Ley 24.241).

J) «S., M. A.»

Hizo lugar — casi por unanimidad ${ }^{85}$ - a la queja por recurso extraordinario denegado articulada por el demandante en el marco de una acción de amparo y decidió revocar la sentencia de la Sala III. ${ }^{a}$ de la Cámara Federal de la Seguridad Social que, confirmando el fallo de primera instancia, había desestimado la pretensión de aquél dirigida a que se le acordara la pensión derivada del fallecimiento de su cónyuge.

${ }^{84}$ Asimismo consignó que, a partir de la doctrina sentada en Fallos, 319:2779, la autoridad administrativa no pudo negar validez al matrimonio extranjero de la peticionaria invocado para solicitar el beneficio previsional, pues la motivación principal que en un precedente anterior del Tribunal había justificado tal solución (Fallos, 273:363), ya no tenía razón de ser frente a la recepción en el derecho matrimonial argentino del anunciado principio de disolubilidad matrimonial por divorcio.

${ }^{85}$ Con la solitaria disidencia de la doctora Argibay, votaron coincidentemente los ministros Petracchi, Highton de Nolasco, Fayt, Maqueda, Zaffaroni y Lorenzetti. 
En suma, y como lo postulaba la Procuradora Fiscal subrogante, dejó sin efecto la resolución cuestionada, que se sustentaba en la convergencia de la causal contemplada en el inc. 'b' del art. 1 de la Ley $17.562^{86}$ por haber quedado el demandante excluido del juicio sucesorio de su cónyuge extinta, de quien estaba separado de hecho.

Juzgó que el hecho de que el actor hubiera sido excluido de la herencia de su ex esposa en los términos del art. 3575 del Código Civil, por encontrarse separado de hecho sin voluntad de unirse a la fecha del deceso, no implicó ser declarado indigno para suceder ni desheredado. Ello, sumado a que los requisitos para acceder a la prestación habían sido comprobados por la autoridad administrativa, a que el accionante fue indebidamente privado del goce de sus haberes por la Administradora de Fondos de Jubilaciones y Pensiones accionada y a la gravedad del estado de salud de aquél, llevó al Tribunal a ordenar que la demandada hiciera efectivo de modo inmediato el pago de las mensualidades de la pensión reconocida por la ANSeS desde el 17 de mayo de 2000.

K) «Badaro I y II»

Aunque abandonemos por un instante la línea cronológica, por razones metodológicas corresponde examinar aquí en forma conjunta ambas sentencias pues ellas corresponden al mismo caso. Por tanto, y para distinguirlas, las identificaremos como «Badaro I» $\mathrm{y}$ «Badaro II».

\section{a) «Badaro I»}

Enfatizó en forma unánime ${ }^{87}$ que la efectividad de la cláusula constitucional sobre la movilidad jubilatoria (art. 14 bis) debe resguardarse legislando sobre el punto (consid. $6^{\circ}$ ). En dirección convergente puntualizó que «el precepto constitucional de la movilidad se dirige primordialmente al legislador, que es el que tiene la facultad de establecer los criterios que estime adecuados a la realidad, mediante una reglamentación que presenta indudable limitación, ya que no puede alterarla (art. 28) sino conferirle la extensión y comprensión previstas en el texto que la enunció y que manda a asegurarla» (consid. 15). Además, puso de

\footnotetext{
${ }^{86}$ Que excluye al causahabiente del beneficio de pensión en casos de indignidad para suceder o desheredación.

${ }^{87}$ El fallo lleva la firma de los siete integrantes con que el Tribunal contaba al momento de emitirlo (y que aún hoy siguen integrándolo, aunque ahora bajo la presidencia del doctor Lorenzetti que sucedió en dicho cargo a su colega Petracchi), ministros Petracchi, Highton de Nolasco, Fayt, Maqueda, Zaffaroni, Lorenzetti y Argibay.
} 
manifiesto que «la ausencia de aumentos en los haberes del demandante no aparece como el fruto de un sistema válido de movilidad, pues la finalidad de la garantía constitucional en juego es acompañar a las prestaciones en el transcurso del tiempo para reforzarlas a medida que decaiga su valor con relación a los salarios de actividad", de lo que extrajo que «la falta de corrección en una medida que guarde relación con el deterioro sufrido, como acontece en autos, configura un apartamiento del mandato del art. 14 bis de la Constitución Nacionali" (sobremarcado agregado; consid. 13).

Precisó además que «no sólo es facultad sino también deber del legislador fijar el contenido concreto de la garantía constitucional en juego, teniendo en cuenta la protección especial que la Ley Suprema ha otorgado al conjunto de los derechos sociales, ya que en su art. 75, incs. 19 y 23, impone al Congreso proveer lo conducente al desarrollo humano y al progreso económico con justicia social, para lo cual debe legislar y promover medidas de acción positiva que garanticen el pleno goce de los derechos reconocidos, en particular, a los ancianos, norma que descalifica todo accionar que en la práctica lleve a un resultado que afecte tales derechos» (consid. 17).

Tal percepción del tema debe leerse en línea con lo que el Tribunal sostuvo en la nombrada causa «Sánchez» (consid. $3 .^{\circ}$ ), en punto a rechazar toda inteligencia restrictiva de la obligación que impone al Estado otorgar 'jubilaciones y pensiones móviles', según el art. 14 bis de la C.N. y a que los tratados internacionales vigentes obligan a adoptar todas las medidas necesarias para asegurar el progreso y la plena efectividad de los derechos humanos, compromiso que debe ser inscripto, además, dentro de las amplias facultades legislativas otorgadas por el art. 75, inc. 23, ibid., con el fin de promover mediante acciones positivas el ejercicio y goce de los derechos fundamentales reconocidos, en particular, a los ancianos.

Retomando la referencia a «Badaro», la Corte — mostrándose consciente de sus límites - advirtió que no era apropiado fijar ella misma sin más «la movilidad que cabe reconocer en la causa, pues la trascendencia de esa resolución y las actuales condiciones económicas requieren de una evaluación cuidadosa y medidas de alcance general y armónicas, debido a la complejidad de la gestión del gasto público y las múltiples necesidades que está destinado a satisfacer» (consid. 16). Consiguientemente, dispuso «llevar a conocimiento de las autoridades que tienen asignadas las atribuciones para efectuar las correcciones necesarias que la omisión de disponer un ajuste por movilidad en el beneficio del actor ha llevado a privarlo de un derecho conferido por la Ley Fundamental», difiriendo su pronunciamiento sobre el período cuestionado por un plazo que resulte suficiente para el dictado de las disposiciones pertinentes (consid. 19). 
b) «Badaro II»

Para relatar sintéticamente la cuestión, cabe recordar que en el pronunciamiento relevado en el subap. anterior la Corte comunicó a las autoridades competentes que en un plazo razonable debían garantizar el cumplimiento del art. 14 bis de la C.N., es decir, la movilidad de los haberes provisionales en el segmento correspondiente al beneficio del demandante.

Al haber transcurrido un lapso de tiempo prudencial (un poco más de quince meses) $\sin$ haber recibido una respuesta satisfactoria sobre el particular ${ }^{88}$, y añadir que el primer fallo dictado en la causa «fue preciso al detallar la omisión legislativa que la Corte había advertido y el daño derivado de ella», en forma unánime ${ }^{89}$ declaró la inconstitucionalidad del art. 7 , inc. 2 , de la Ley $\mathrm{N} .{ }^{\circ}$ 24.463 , en el caso, y determinó que la prestación del accionante (que supera los $\$ 1.000$ ) se ajuste, entre el $1 .^{\circ}$ de enero de 2002 y el 31 de diciembre de 2006, de acuerdo con las variaciones anuales del índice de salarios, nivel general, elaborado por el Instituto Nacional de Estadísticas y Censos, ordenando además a la ANSeS que abone el nuevo haber y practique liquidación de las retroactividades pertinentes más los intereses de acuerdo con la tasa pasiva.

Para arribar a tal solución, y entre otras apreciaciones, argumentó que si bien eran constitucionales los cambios de los regímenes de movilidad, esto es, el reemplazo de un método de determinación de incrementos por otro a los fines de lograr una mejor administración o de dar mayor previsibilidad financiera al sistema de seguridad social, el reconocimiento de esa facultad se encontraba sujeto a una indudable limitación, ya que tales modificaciones no pueden conducir a reducciones confiscatorias en los haberes.

Y como el único aumento en el beneficio jubilatorio del accionante que se dispuso durante el período reclamado (enero de 2002 a diciembre de 2006) era

${ }^{88}$ Luego del fallo «Badaro I» el Congreso dictó la Ley 26.198, aprobatoria del presupuesto 2007 , que reconoció un aumento general del $13 \%$ con vigencia desde el $1 .^{\circ}$ de enero de 2007 , convalidó los aumentos de los haberes inferiores a \$ 1.000 implementados por distintos decretos de necesidad y urgencia y facultó al Ejecutivo para conceder incrementos adicionales, lo cual se concretó por medio del Decreto 1.346/2007 que estableció un aumento general del 12,5\% a partir del $1 .^{\circ}$ de septiembre de 2007.

Del breve repaso anterior se observa claramente que, en definitiva, ninguna de las medidas descriptas previó la razonable movilidad de los beneficios jubilatorios en el período reclamado por el demandante: $1 .^{\circ}$ de enero de 2002 a 31 de diciembre de 2006; con lo cual quedaba incumplido lo resuelto en «Badaro I».

89 Votaron los ministros ministros Petracchi, Highton de Nolasco, Fayt, Maqueda, Zaffaroni y Lorenzetti. 
insuficiente para reparar su deterioro, consideró procedente declarar en el caso la inconstitucionalidad del régimen de movilidad aplicable y ordenar su sustitución y el pago de las diferencias pertinentes.

Finalmente, y más allá de la solución puntual adoptada, el Tribunal manifestó que contribuiría a la seguridad jurídica el dictado de una ley que establezca pautas de aplicación permanentes que aseguren el objetivo constitucional relativo a la movilidad de las prestaciones provisionales, pues una reglamentación prudente de la garantía en cuestión, además de facilitar el debate anual sobre la distribución de recursos y evitar el uso de las facultades discrecionales, permitiría reducir la litigiosidad en esta materia, que ha redundado en menoscabo de los derechos de los justiciables y del adecuado funcionamiento del Poder Judicial. Por tal motivo, formuló una nueva exhortación a las autoridades responsables a fin de que examinen dicha problemática.

\section{L) «Rinaldi»}

Optó aquí por no declarar la inconstitucionalidad del régimen de refinanciación hipotecaria en el marco de la pesificación de la obligación en moneda extranjera en un contrato de mutuo con garantía hipotecaria de vivienda única y familiar (art. 14 bis de la Ley Fundamental), desestimando el planteo que en tal sentido se dirigía contra la Ley $26.167^{90}$, y que fuera incoado cuando la causa ya se encontraba en poder de la Corte. Dispuso, en definitiva, que en las ejecuciones de mutuos hipotecarios celebrados entre particulares en divisa extranjera y por un monto inferior a $\$ 100.000$, en los que el deudor tenga comprometida su vivienda única y familiar, el reajuste equitativo de las prestaciones al que se refiere el art. 11 de la Ley $25.561^{91}$, no podrá exceder el cálculo que surge de la conversión de un dólar a un peso más el $30 \%$ de la diferencia entre dicha paridad y la cotización libre del dólar a la fecha en que se practique la liquidación, debiendo adicionarse un interés que no sea superior al 2,5\% anual por todo concepto, desde la mora hasta su efectivo pago. Ello, por aplicación de lo previsto en el art. 6 de la Ley 26.167.

El voto mayoritario ${ }^{92}$ puntualizó que ante la posibilidad de que un número muy importante de deudores hipotecarios pudieran ver en peligro la subsisten-

90 B.O. de 29 de noviembre de 2006.

91 B.O. de 7 de enero de 2002.

${ }_{92}$ El voto que encabeza la sentencia correspondió a los ministros Highton de Nolasco y Maqueda; concurrentemente, en forma conjunta y coincidiendo con éstos en sus primeros once considerandos, se expidieron los doctores Lorenzetti y Zaffaroni; y, finalmente, la doctora Argibay se expidió por su voto. 
cia de las garantías contempladas por el citado art. 14 bis, las medidas legislativas tendientes al afianzamiento de la vivienda familiar — entre las que debía incluirse a las Leyes $25.798^{93}$ y $25.908^{94}$, que habían quedado subsumidas en la Ley 26.167- obedecían a un propósito de justicia (cfr. Fallos, 249:183), y la razonabilidad de las mayores restricciones que aquéllas imponían al derecho de propiedad del acreedor, debían valorarse en función de la entidad de la crisis que buscaba superarse (consid. 47).

\section{El enfoque del problema a través de ciertas importantes acordadas del Tribunal}

Abandonando el plano contencioso y para graficar lo expresado en torno de las acordadas de la Corte Suprema, basta pasar revista a las siguientes:

\section{A) N. ${ }^{\circ} 28 / 04$}

En esta acordada ${ }^{95}$, de 14 de julio de 2004, reglamentó - por mayoría ${ }^{96}$ - la intervención de "amigos del Tribunal» ${ }^{97}$ (amicus curiae) en procesos judiciales correspondientes a su competencia originaria o apelada en los que se debatan asuntos de trascendencia colectiva o interés general.

93 B.O. de 7 de noviembre de 2003.

94 B.O. de 13 de julio de 2004.

95 Para un análisis de la aludida acordada, ver BAZÁN, Víctor, «El amicus curiae en el derecho comparado y su instrumentación reglamentaria por la Corte Suprema de Justicia argentina», Anuario Iberoamericano de Justicia Constitucional, N. ${ }^{\circ}$ 10, Centro de Estudios Políticos y Constitucionales, Madrid, 2006, págs. 15/50, en esp., págs. 29/44.

${ }^{96} \mathrm{La}$ acordada en cuestión contó con la rúbrica aprobatoria de los ministros Petracchi, Boggiano, Maqueda, Zaffaroni y Highton de Nolasco, y las disidencias de los doctores Belluscio, Fayt y Vázquez.

97 Venimos bregando desde hace tiempo por la instauración de la figura, razón por la que en su momento nos expedimos laudatoriamente cuando la Corte Suprema se animó a adoptarla aun sin ley genérica en la materia.

También saludamos con beneplácito que se hayan plegado a tal temperamento otros importantes tribunales de los ámbitos provincial, por ejemplo, la Suprema Corte de Justicia de Mendoza, cuya Sala Primera admitió la figura por vez primera en la causa N. ${ }^{\circ}$ 83.665: «Curel, Gastón Oscar y ots. en J..$^{\circ}$ 30.554/114.678, Mancilla Cuello, Enrique Ariel y ots. c/ Municipalidad de la Ciudad de Mendoza p/ Ac. de Amp. s/ Inc.", resuelta el 3 de febrero de 2006; y nacional, refiriéndonos en este caso a la Cámara Nacional Electoral —autoridad superior en materia electoral de acuerdo con el art. 5 de la Ley 19.108, modificada por Ley 19.277-, que ha reglamentado recientemente el instituto por medio de la Acordada Extraordinaria N. . 85, de 19 de julio de 2007. 
Entre otros fundamentos para avalar la instauración de la figura del amicus curiae, la posición mayoritaria precisó que la actuación de éstos encuentra sustento en el sistema interamericano al cual se ha asignado jerarquía constitucional (art. 75, inc. 22, de la C.N.), pues ha sido objeto de regulación en el Reglamento de la Corte Interamericana (art. 62.3) y ha sido expresamente autorizada por la Comisión Interamericana con sustento en los arts. 44 y 48 de la $\mathrm{CADH}$ (ver, el consid. 2. ${ }^{\circ}$, parte in fine, del Acuerdo).

Es de destacar que si la mayoría de los Estados latinoamericanos ha aceptado la jurisdicción contenciosa de la Corte Interamericana de Derechos Humanos, si además ante ésta existe la posibilidad de comparecer en calidad de amicus curiae y si llegar con un caso ante la misma supone el agotamiento previo de los recursos internos del Estado demandado, requisito éste concedido en interés del propio Estado, resulta entonces absurdo - como enfatizan ABREGÚ y COURTIS $^{98}$ - prohibir a instituciones o grupos interesados presentarse en carácter de amicus ante los tribunales locales (oportunidad frente a la que el Estado tiene posibilidades de remediar la alegada violación) y conceder esa posibilidad después, cuando el Estado ya ha sido demandado ante la Corte por la imputación de los mismos hechos. Por lo demás, siendo la instancia interamericana coadyuvante o complementaria de la que exhibe el derecho interno, es razonable ofrecer a los grupos o instituciones interesados en articular opiniones fundadas sobre el tema en cuestión la misma posibilidad de participación procesal en sede interna que la que tienen en el ámbito internacional, adelantando ante los tribunales locales los argumentos que eventualmente serán considerados por el Tribunal con sede en Costa Rica.

B) N. ${ }^{\circ} 17 / 05$

Por medio de esta acordada ${ }^{99}$, de 2 de agosto de 2005, dispuso asignar a su Secretaría Judicial N. ${ }^{\circ} 6$ el trámite de las causas concernientes a su competencia apelada, en las cuales sea puesta en juego, de manera directa, inmediata y trascendente, la interpretación y aplicación del derecho de los derechos humanos.

Más allá de la parte dispositiva, resultan remarcables algunos segmentos de su fundamentación, por ejemplo, aquellos en los que - entre otras apreciacio-

98 ABREgú, Martín y CoURTIS, Christian, «Perspectivas y posibilidades del amicus curiae en el derecho argentino", op. cit. en nota 9, págs. 392/393.

99 Suscripta por los doctores Petracchi, Belluscio, Maqueda, Zaffaroni, Highton de Nolasco, Lorenzetti y Argibay. 
nes — califica de "hito mayúsculo» al reconocimiento de jerarquía constitucional de los mayores instrumentos internacionales de derechos humanos (párr. 3. ${ }^{\circ} \mathrm{de}$ los considerandos), lo que — sigue exponiendo el Tribunal — dio lugar a una singular recepción en la cumbre del ordenamiento jurídico argentino al derecho internacional de los derechos humanos, produciendo tres importantes consecuencias, al menos: «[e]n primer lugar, introdujo nuevos derechos o imprimió nuevos contenidos a los ya existentes. En segundo término, puso en cabeza del Estado obligaciones relativas al respeto, protección y realización de los derechos humanos de toda persona sometida a su jurisdicción. Finalmente, emplazó a nuestro país en sistemas internacionales de control del cumplimiento de los aludidos compromisos» (párr. $4 .^{\circ}$ de los considerandos).

En ese sentido, manifestó que la prescindencia de las normas internacionales por los órganos estatales -incluidos los de carácter jurisdiccional- puede originar responsabilidad internacional del Estado argentino, por lo que juzgó aconsejable que en los casos de competencia apelada en los cuales se ponga en juego, de la manera indicada precedentemente, la interpretación y la aplicación del derecho de los derechos humanos, tramiten por una secretaría judicial especializada en la materia (párr. 6. ${ }^{\circ}$ de los considerandos).

Entendemos que el sustento argumental que da base a la acordada es elocuente y la finalidad de ésta desborda con amplitud el mero cumplimiento de una función instrumental o de ordenamiento administrativo. Por el contrario, se presenta como una muestra evidente más de la firme posición institucional que adopta la Corte al reforzar axiológica y jurídicamente su compromiso, como Poder del Estado, frente al derecho de los derechos humanos en las causas que arriben a sus estrados.

C) $\mathrm{N} \cdot{ }^{\circ} 12 / 07$

Es un secreto a voces que la Corte Suprema está dispuesta, fundamentalmente a partir de su nueva composición, a reconfigurar su perfil institucional, fortalecer su rol de cabeza de uno de los Poderes del Estado y centrar sus mayores esfuerzos en cuestiones relevantes desde el plano constitucional, con lo cual camina hacia la figura de un tribunal constitucional al menos desde la dimensión material ${ }^{100}$.

100 Entre otros trabajos de BAZÁN, Víctor, al respecto, ver «La reconfiguración del rol institucional de la Corte Suprema de Justicia argentina y el camino hacia su consolidación como un tribunal constitucional», Anuario de Derecho Constitucional Latinoamericano 2008, Fundación Konrad Adenauer, Montevideo, en prensa. 
Con ese telón de fondo, dictó en fecha 3 de julio de 2007 la acordada en cuestión $^{101}$, creando en el ámbito de la Corte, y con dependencia directa de su Presidente, la Oficina de Fortalecimiento Institucional, con el objeto de contribuir a profundizar la transparencia de los trámites judiciales y permitir un adecuado control por parte de todos a quienes concierne e interesa el mejor funcionamiento del Poder Judicial; de facilitar el acceso eficiente a la información jurídica procurando una activa participación de aquellos sectores que, por su rol institucional, tienen mayor responsabilidad en la administración de justicia; $\mathrm{y}$, entre otras cosas y en suma, de garantizar a toda la población, en condiciones de igualdad, el efectivo acceso a la jurisdicción y a un pronunciamiento oportuno y eficaz sobre las cuestiones que se traen a conocimiento de los jueces.

En definitiva, el propósito primordial que persigue el acuerdo aquí colacionado, consiste en la indispensabilidad de adoptar nuevas medidas que permitan profundizar el proceso de fortalecimiento del Poder Judicial como condición esencial para garantizar el imperio del Estado de Derecho y el funcionamiento armónico de las instituciones de la República.

\section{D) N. ${ }^{\circ} 14 / 07$}

Sustentándose en que venía tomando conocimiento de diversas circunstancias de naturaleza administrativa y funcional, que obstaculizan o dificultan la adecuada tramitación de gran cantidad de causas penales concernientes a la presunta violación de derechos humanos en hechos ocurridos antes del 10 de diciembre de $1983^{102}$, radicadas ante tribunales federales de distinta instancia en todo el territorio de la República Argentina; el 11 de julio de $2007^{103}$ emitió tal acordada por cuya virtud crea en el ámbito de la Corte Suprema una Unidad de Asistencia y Seguimiento de las Causas Penales en las que se investiga la desaparición forzada de personas, acaecidas antes del 10 de diciembre de 1983, unidad que operará transitoriamente hasta concluir con la misión encomendada.

101 Firmada por los ministros Lorenzetti, Highton de Nolasco, Fayt, Maqueda y Argibay.

102 Fecha histórica en Argentina por el renacimiento democrático luego del último gobierno de facto comenzado en marzo de 1976.

${ }^{103}$ Firmada por los ministros Lorenzetti, Highton de Nolasco, Petracchi, Maqueda, Zaffaroni y Argibay. 
E) N. ${ }^{\circ} 30 / 07$

Dictada el 5 de noviembre de 2007, y firmada por todos sus integrantes ${ }^{104}$, la Corte dio un importante paso institucional al implementar el régimen de audiencias públicas.

Desde nuestro punto de vista, y como hemos sostenido en reiteradas ocasiones, tanto ese tipo de audiencias de carácter público en la Corte Suprema como la intervención ante ésta de amici curiae, constituyen herramientas de utilidad para fortalecer la cotización cualitativa del debate judicial y aportar ingredientes para su democratización, al ampliarse los criterios de participación en los procesos en que se ventilen asuntos de trascendencia institucional, interés público y/o que contengan cuestiones jurídica y/o axiológicamente controvertidas o dilemáticas.

Entre otros fundamentos, la Corte manifestó que la participación ciudadana en dichas audiencias y la difusión pública del modo en que conoce de los asuntos en que, con carácter primordial, ha de ejercer la jurisdicción más eminente que le confiere la Constitución Nacional, permitirá poner a prueba directamente ante los ojos del país la eficacia y objetividad de la administración de justicia que el Tribunal realiza ${ }^{105}$.

Por último, puede acotarse que el acuerdo en cuestión prefigura tres clases de audiencias públicas: a) informativa, para escuchar e interrogar a las partes sobre aspectos del caso por decidir; b) conciliatoria, que tendrá por objeto instar a las partes en la búsqueda de soluciones no adversariales; y c) ordenatoria, en orden a tomar las medidas que permitan encauzar el procedimiento a fin de mejorar la tramitación de la causa.

\section{LOS CRITERIOS EXHIBIDOS POR LA CORTE SUPREMA FRENTE A LOS PRONUNCIAMIENTOS DE LA CORTE Y LA COMISIÓN INTERAMERICANAS DE DERECHOS HUMANOS Y OTROS ÓRGANOS INTERNACIONALES COMPETENTES EN LA MATERIA}

\section{Aclaración previa}

Si bien aquí centraremos principalmente nuestra atención en los pronunciamientos de la Corte y la Comisión Interamericanas de Derechos $\mathrm{Hu}$ -

104 O sea, rubricada por los doctores Lorenzetti, Highton de Nolasco, Petracchi, Fayt, Maqueda, Zaffaroni y Argibay.

105 El párrafo transcripto correspone al dictamen del Procurador General de la Nación en la causa «Penjerek», al que remite la sentencia de la Corte de 14 de noviembre de 1963 (Fallos, 257:134). 
manos, no puede omitirse indicar siquiera tangencialmente que en algunos fallos de la Corte Suprema argentina se citan y tienen en cuenta las recomendaciones y observaciones de otros órganos de supervisión en materia de derechos humanos ya en el plano universal, por ejemplo, el Comité de Derechos Económicos, Sociales y Culturales, el Comité de los Derechos del Niño y el Comité de Derechos Humanos, tópico respecto del cual intercalaremos una breve referencia.

\section{Sobre los pronunciamientos de la Corte Interamericana}

Comenzando entonces a desandar el itinerario anunciado, vemos que ya antes de la innovación constitucional de 1994, concretamente en «Ekmekdjian c/ Sofovich» (de 7 de julio de 1992), y dando un giro copernicano en su percepción jurisprudencial, la Corte Suprema transfundió en su fallo la hermenéutica que la Corte Interamericana realizara respecto de la $\mathrm{CADH}$, sosteniendo precisamente que la interpretación de ésta debe guiarse por la jurisprudencia del Tribunal interamericano ${ }^{106}$, para pasar a citar aprobatoriamente la Opinión Consultiva (OC) 7/86 107 (ver consid. 21 y ss. de la mayoría),

106 «Ekmekdjian, Miguel Ángel c/ Sofovich, Gerardo y otros», Fallos, 315:1492. El criterio trasuntado en tal resolutorio aparece también de algún modo esbozado en «Servini de Cubría, María R. s/ amparo", de 8 de setiembre de 1992 (Fallos, 315:1943).

Es importante recordar, ya respecto de la valencia prioritaria del derecho internacional convencional sobre el derecho interno y la necesaria aplicación del art. 27 de la Convención de Viena sobre el Derecho de los Tratados, que en «Ekmekdjian c/ Sofovich» la Corte Suprema estableció (ver consids. 18 a 20 del voto mayoritario) que, en orden a evitar confusiones interpretativas que lesionaran la supremacía de la Constitución (y su art. 27), se veía precisada a estrechar la primigenia laxitud de aquella afirmación, al declarar en fallos posteriores que «el art. 27 de la Convención de Viena sobre el Derecho de los Tratados impone a los órganos del Estado argentino una vez resguardados los principios de derecho público constitucionales-asegurar la primacía a los tratados ante un conflicto con una norma interna contraria pues esa prioridad de rango integra el orden jurídico argentino y es invocable con sustento en el art. 31 de la Carta Magna» - bastardilla nuestra- ("Cafés La Virginia S.A.», de 13 de octubre de 1994, Fallos, 317:1282, consid. 9. e la mayoría, y su remisión a "Fibraca Constructora SCA c/ Comisión Técnica Mixta de Salto Grande», de 7 de julio de 1993, Fallos, 316:1669, consid. 3. ${ }^{\circ}$ ).

Algún pronunciamiento anterior a «Ekmekdjian c/ Sofovich» sobre la interpretación de la normativa de un instrumento internacional se patentiza embrionariamente en el caso «Firmenich, Mario E.», de 28 de julio de 1987 (Fallos, 310:1476), acerca de la hermenéutica «razonable» del art. 7.5 de la $\mathrm{CADH}$ (ver consids. $4 .^{\circ}, 6 .^{\circ}$ y $7 .^{\circ}$ de la mayoría).

107 Corte IDH, OC-7/86, de 29 de agosto de 1986, «Exigibilidad del derecho de rectificación o respuesta (arts. 14.1, 1.1 y 2, Convención Americana sobre Derechos Humanos)", Serie A, Fa- 
en la que —entre otros aspectos— la Corte Interamericana interpretó el art. 14.1 del Pacto ${ }^{108}$.

Sin perjuicio de ello, aquel temperamento quedó nítidamente configurado en "Giroldi», en el que la Corte Suprema sostuvo que la expresión «en las condiciones de su vigencia», bajo la que adquiere jerarquía constitucional la $\mathrm{CADH}$ (art. 75 , inc. 22, párr. $2^{\circ}$ ), significa el modo como ella rige en el ámbito internacional y «considerando particularmente su efectiva aplicación jurisprudencial por los tribunales internacionales competentes para su interpretación y aplicación, de ahí que la aludida jurisprudencia deba servir de guía para la interpretación de los preceptos convencionales en la medida en que el Estado argentino reconoció la competencia de la Corte Interamericana para conocer en todos los casos relativos a la interpretación y aplicación de la Con-

llos y Opiniones, N. ${ }^{\circ}$, Secretaría de la Corte Interamericana de Derechos Humanos, San José de Costa Rica, 1986.

${ }^{108} \mathrm{La}$ jurisprudencia de la Corte Interamericana nutre, asimismo, a los votos individuales y/o disidentes de algunos de los ministros de la Corte Suprema. Por caso, y sin intenciones de taxatividad, en «Ekmekdjian c/ Sofovich» así puede ser constatado de la lectura del voto disidente de los doctores Petracchi y Moliné O’Connor, cuyo consid. 14 refleja la cita de la OC-2/82 (de 24 de septiembre de 1982, «El efecto de las reservas sobre la entrada en vigencia de la Convención Americana sobre Derechos Humanos [arts. 74 y 75]», Serie A: Fallos y Opiniones, N. ${ }^{\circ} 2$, Secretaría de la Corte Interamericana de Derechos Humanos, San José de Costa Rica, 1982) y de la OC-1/82 (de 24 de septiembre de 1982, «'Otros tratados’ objeto de la función consultiva de la Corte [art. 64 Convención Americana sobre Derechos Humanos]», Serie A: Fallos y Opiniones, N. ${ }^{\circ}$ 1, Secretaría de la Corte Interamericana de Derechos Humanos, San José de Costa Rica, 1982), el consid. 16 de la OC-7/86 y de la OC-2/82 y el consid. 17, nuevamente de la OC-7/86 —específicamente, la opinión separada del juez Gros Espiell-; ya en el voto, también disidente, del doctor Levene (h.), en el consid. 9. - bien que implícitamente- se alude a la OC-2/82 y a la OC-3/83 (de 8 de septiembre de 1983, «Restricciones a la pena de muerte [arts. 4.2 y 4.4 Convención Americana sobre Derechos Humanos]», Serie A: Fallos y Opiniones, N. ${ }^{\circ} 3$, Secretaría de la Corte Interamericana de Derechos Humanos, San José de Costa Rica, 1983) y en el consid. 10, a la OC-7/86.

Por su parte, en «Servini de Cubría», en el consid. 25 del voto del doctor Fayt se alude a la citada OC-5/85; referencia reiterada en el voto del doctor Boggiano — consids. 15 a 17, donde también se alude a la opinión separada del juez Gros Espiell—, en la disidencia parcial del doctor Barra - consids. 12 a 14, tramos donde figuran asimismo referencias a las opiniones separadas de los jueces Piza Escalante y Gros Espiell—y en la disidencia parcial del doctor Petracchi —consids. 25 y 26 -.

Ya en el pronunciamiento vertido en «Artigue, Sergio P.», de 25 de marzo de 1994 (Fallos, 317:247), en el consid. 14 del voto del doctor Petracchi se cita la mencionada OC-7/86 —opinión separada del juez Piza Escalante-. 
vención Americana» ${ }^{109}$ (arts. 75, de la C.N., $62^{110}$ y $64^{111}$ de la CADH, y 2 de la Ley $23.054^{112}$ ).

No puede ocultarse, sin embargo, que si bien aquella posición jurisprudencial ha sido mantenida en líneas generales por la Corte Suprema, no ha dejado de sufrir algunos avatares, por ejemplo, en el caso "Cantos», en el cual desestimó por mayoría ${ }^{113}$ una presentación del Procurador General del Tesoro que pretendía que el Tribunal diera cumplimiento a una sentencia de la Corte Interamericana que había declarado que el Estado argentino violó normas de la $\mathrm{CADH}$ y que debía abstenerse de perseguir el cobro de la tasa de justicia y de una multa impuesta, reducir razonablemente los honorarios regulados y asumir el pago de costas en una causa donde fue parte. El Tribunal declinó la intervención requerida, aduciendo que un temperamento contrario importaría infringir cláusulas de raigambre constitucional cuya titularidad corresponde a diversos profesionales que actuaron en la causa "C.1099.XX, 'Cantos, José María c/ Santiago del Estero, Provincia de y/o Estado Nacional s/ cobro de pesos'», con patente y deliberada renuncia de su más alta y trascendente atribución, para cuyo ejercicio ha sido instituida como titular del Poder Judicial de la Nación, que es ser el custodio e intérprete final de la C.N. (consid. 3. ${ }^{\circ}$ de la mayoría). Además, y entre otros argumentos, sostuvo que, «bajo el ropaje de dar cumplimiento con una obligación emanada de un tratado con jerarquía constitucional (art. 63.1, de la Convención), llevaría a la inicua — cuanto paradójica - situación, de hacer incurrir al Estado argentino en responsabilidad internacional por afectar garantías y derechos reconocidos a los profesionales,

109 «Giroldi, Horacio D. y otro s/ recurso de casación», de 7 de abril de 1995 (Fallos, 318:514 — consids. 11 y 5. - - . Ver, en sentido coincidente, Moncayo, Guillermo R., "Criterios para la aplicación de las normas internacionales que resguardan los derechos humanos en el derecho argentino", op. cit. en nota 9 , pág. 92.

110 Que determina la oportunidad en que los Estados Partes de la CADH pueden declarar el reconocimiento de la competencia de la Corte Interamericana, y fija los alcances, modalidades y efectos de esa declaración.

111 Referido a la competencia consultiva del Corte Interamericana.

112 Mediante la Ley 23.054, la República Argentina aprobó la CADH. Específicamente el art. 2 de dicha ley plasma el reconocimiento argentino de la competencia de la Comisión y la Corte Interamericanas.

113 «Procurador del Tesoro de la Nación (en Autos 'Cantos, José M., expediente 1.307/2003')», de 21 de agosto de 2003 (Fallos, 326:2968). La mayoría estuvo compuesta por los doctores Fayt y Moliné O’Connor; por su voto, lo hicieron los ministros Petracchi y López (de modo conjunto) y Vázquez (individualmente); por último, los jueces Boggiano y Maqueda plantearon sendas disidencias, siendo relevante remarcar que este último mocionó el cumplimiento directo del pronunciamiento de la Corte Interamericana. 
precisamente, en el instrumento cuyo acatamiento se invoca» (consid. $4 .^{\circ}$ del voto mayoritario).

Ya en un caso más reciente, "Espósito», la Corte Suprema retomó —al menos por parte de varios de sus componentes - un discurso demostrativo de su permeabilidad a acatar los pronunciamientos del Tribunal con sede en Costa Rica, al admitir mayoritariamente ${ }^{114}$ el recurso extraordinario deducido contra una sentencia que había declarado extinta la acción penal por prescripción en una causa abierta por hechos que luego fueron juzgados por dicha Corte Interamericana, cuyas decisiones — sostuvo la Corte Suprema - resultan de «cumplimiento obligatorio para el Estado argentino (art. 68.1, CADH)», por lo cual también ella, en principio, debe subordinar el contenido de sus decisiones a las de dicho tribunal internacional (consid. $6 .^{\circ}$ de la mayoría). Previo a ello, puntualizó que el rechazo de la apelación tendría como efecto inmediato la confirmación de la declaración de prescripción de la acción penal, en contravención a lo decidido por la Corte Interamericana en su sentencia de 18 de setiembre de 2003 en el caso "Bulacio c/ Argentina", en el que se declarara la responsabilidad internacional del país - entre otros puntos- por la deficiente tramitación del expediente en cuestión (consid. $5 .^{\circ}$ del voto triunfante).

Buena muestra del nivel de acatamiento que a los fallos de la Corte Interamericana pregona el Máximo Tribunal argentino, proporcionan — - v.gr.- las nombradas sentencias recaídas en "Arancibia Clavel» y «Simón», donde las respectivas mociones mayoritarias siguieron muy de cerca a un pronunciamiento fundamental de la jurisprudencia interamericana: el nombrado "Caso Barrios Altos ${ }^{115}$. Fundamentalmente, le proporcionaron útiles aportes de hermenéutica y aplicación jurídicas ${ }^{116}$ las consideraciones sobre la inadmisibilidad de las disposiciones de amnistía, de prescripción y el establecimiento de excluyentes de responsabilidad «que pretendan impedir la investigación y sanción de los responsables de las violaciones graves de los derechos humanos tales como la tortura, las ejecuciones sumarias, extralegales o arbitrarias y las desapariciones for-

114 «Espósito, Miguel Ángel s/ incidente de prescripción de la acción penal promovido por su defensa", de 23 de diciembre de 2004 (Fallos, 327:5668). Formaron la mayoría los doctores Petracchi y Zaffaroni; por su voto, lo hicieron los doctores Belluscio y Maqueda (conjuntamente), y Fayt, Boggiano y Highton de Nolasco, de modo individual.

115 Corte IDH, «Caso Barrios Altos», cit., sentencia de fondo de 14 de marzo de 2001, e interpretación de la sentencia de fondo, art. 67 de la CADH, de 3 de setiembre de 2001, Serie C, N. ${ }^{\circ}$ 83, San José de Costa Rica.

116 Consultar en los respectivos votos dominantes, por ejemplo, los considerandos 35 y 36 en «Arancibia Clavel» y 23 y 24 de «Simón». 
zadas, todas ellas prohibidas por contravenir derechos inderogables reconocidos por el Derecho Internacional de los Derechos Humanos» ${ }^{117}$.

\section{En torno a los informes de la Comisión Interamericana}

Desde otro perfil, no es aconsejable que la Corte Suprema se desentienda de la relevancia de los informes y recomendaciones de la Comisión Interamericana, respecto de cuya cotización jurídica aquel Tribunal ha descripto una trayectoria jurisprudencial ondulante.

En efecto, siguiendo los lineamientos sentados en la aludida causa "Giroldi», en «Bramajo» le adjudicó la calidad de "guía para la interpretación de los preceptos convencionales a la opinión de la Comisión Interamericana», en la medida en que el Estado argentino reconoció la competencia de ésta para conocer en todos los casos relativos a la interpretación y la aplicación de la $\mathrm{CADH}$ (consid. 8. ${ }^{\circ}$ del voto de la mayoría) ${ }^{118}$, aunque luego plasmó un repliegue de la amplia posición primigenia, cuando en la causa "Acosta», aclaró que, si bien por el principio de buena fe que rige la actuación del Estado argentino en el cumplimiento de sus compromisos internacionales, éste «debe realizar los mejores esfuerzos para dar respuesta favorable a las recomendaciones efectuadas por la Comisión, ello no equivale a consagrar como deber para los jueces el de dar cumplimiento a su contenido, al no tratarse aquéllas de decisiones vinculantes para el Poder Judicial» (consid. 13 de la mayoría) ${ }^{119}$.

La mutación de la percepción que al respecto exhibe la Corte Suprema puede fácilmente comprobarse a poco de visualizar que, en la misma fecha en que resolvió el caso "Acosta», es decir, el 22 de diciembre de 1998, emitió sentencia en la causa «Nápoli» ${ }^{120}$, en cuyo consid. 18 de la mayoría ${ }^{121}$ reiteró lo ma-

117 Corte IDH, «Caso Barrios Altos», cit., párr. 41 de la sentencia de fondo.

118 «Bramajo, Hernán, J.», de 12 de setiembre de 1996 (Fallos, 319:1840). La mayoría quedó integrada con los doctores Nazareno, Moliné O’Connor, Boggiano, López y Vázquez. En disidencia conjunta votaron los ministros Fayt, Belluscio y Bossert.

119 «Acosta, Claudia B.», de 22 de diciembre de 1998 (Fallos, 321:3555). La mayoría estuvo compuesta por los ministros Nazareno, Moliné O’Connor, Fayt, Belluscio, López y Vázquez. Por su voto se expidieron, conjunta y concurrentemente, los doctores Bossert y Boggiano. Por su parte, el ministro Petracchi lo hizo en disidencia.

120 «Nápoli, Erika Elizabeth y otros s/ infracción art. 139 bis del Código Penal» (Fallos, 321:3630).

${ }^{121}$ El voto mayoritario fue rubricado por los jueces Belluscio, Boggiano, López y Vázquez. Por su voto, lo hizo el ministro Fayt. Finalmente, los doctores Petracchi y Bossert se expidieron en sendas disidencias. 
nifestado en «Giroldi» —incluso reenvió a dicha resolución (concretamente al $2 .^{\circ}$ párr. del consid. 11) — en punto a que la jurisprudencia de la Corte Interamericana de Derechos Humanos debe servir de guía para la interpretación del Pacto de San José de Costa Rica.

Con ello se acredita que el Tribunal quiso dejar en claro la bifurcación de criterios a la que a partir de entonces adscribía, manteniendo su posición en torno a la imperatividad de los decisorios de la Corte Interamericana, refrendada en «Nápoli», y paralelamente decantándose por la no vinculatoriedad de los pronunciamientos de la Comisión Interamericana, que el mismo día comenzó a moldear en «Acosta».

La visión jurídica inoculada a "Acosta» fue confirmada en "Felicetti», causa vinculada con el públicamente conocido copamiento de La Tablada (ver consid. $6 .^{\circ}$ de la mayoría) ${ }^{122}, \mathrm{y}$ - ya tangencialmente- en «Alonso» (consid. $5 .^{\circ}$ del voto mayoritario) $)^{123}$.

Sin embargo, en el citado caso «Simón», el Tribunal (consid. 17 de la mayoría) ha catalogado a la jurisprudencia de la Corte Interamericana y a las directivas de la Comisión Interamericana como "una imprescindible pauta de interpretación de los deberes y obligaciones derivados de la Convención Americana sobre Derechos Humanos» (énfasis añadido), lo que —a salvo cuanto diremos más abajo-, refleja una revalorización de los pronunciamientos de la Comisión.

Y pese a que «Simón» puede leerse como el comienzo del fin de tal dualidad en tanto ha importado un salto cualitativo en la conformación del umbral de lo aceptable, creemos que no se ha llegado aún al ideal que cabe aguardar, es decir, que se aprehenda y consagre la obligatoriedad de los pronunciamientos de la Comisión y no sólo que se vea en ellos su magnitud como parámetros hermenéuticos.

Sólo resta esperar que se consolide, y luego evolucione, la tendencia que el Tribunal cupular nacional recomenzara a escribir en «Simón», retomando — aunque con mayores precisión terminológica y densidad jurídica — la huella dejada en «Bramajo».

122 «Felicetti, Roberto y otros», de 21 de diciembre de 2000 (Fallos, 323:4130). El sentido de los votos emitidos fue el siguiente: por la mayoría, se expidieron los doctores Nazareno, Moliné O’Connor, Belluscio, López y Vázquez; además, hubo sendas disidencias de parte de los ministros Fayt, Petracchi, Boggiano y Bossert.

123 «Alonso, Jorge F. s/ recurso de casación», de 19 de setiembre de 2002 (Fallos, 325:2322). La mayoría estuvo compuesta por los ministros Nazareno, Moliné O’Connor, Belluscio, López y Vázquez; en disidencia lo hicieron los doctores Petracchi y Bossert (conjuntamente) y Boggiano (de manera individual). 


\section{Rápida alusión a otras instancias internacionales de supervisión en materia de derechos humanos}

En relación con el tema anunciado, en varios decisorios la Corte sigue y emplea como pauta hermenéutica el criterio de otros organismos de supervisión ya el contexto universal.

Inter alia, ello se hizo perceptible respecto del Comité de Derechos Económicos, Sociales y Culturales, en la citada causa «Aquino», donde se encargó de poner de relieve la actividad de éste en tanto intérprete autorizado del Pacto Internacional de Derechos Económicos, Sociales y Culturales (PIDESC) en el plano internacional, actuando en las condiciones de vigencia de éste (consid. 8..$^{\circ}$ del voto mayoritario).

Añadió en id. consid. que la actividad de aquél es demostrativa de la gran importancia que dicho Pacto reconoce a la protección del trabajador víctima de un accidente laboral, para lo cual enumera ejemplificativamente la censura del Comité a la «New Zealand Accident Rehabilitation and Compensation Insurance Act», de 1992, en cuanto ponía en cabeza del trabajador víctima de un accidente una parte del costo del tratamiento médico; las «Directrices relativas a la Forma y el Contenido de los Informes que deben presentar los Estados Partes» - elaboradas por el Comité-, y que requieren que éstos den cuenta de las disposiciones legales, administrativas y de otro tipo que prescriban condiciones mínimas de seguridad e higiene laborales y proporcionen los datos sobre el número, la frecuencia y la naturaleza de accidentes o enfermedades - especialmente fatales - o enfermedades en los últimos 10 y 5 años, comparándolos con los actuales; a todo lo que se agregan las advertencias y recomendaciones dirigidas por el Comité a los países en que las leyes de seguridad en el trabajo no se cumplen adecuadamente, como el caso de Argentina, respecto del cual el mencionado órgano de supervisión del Pacto mostró su inquietud con motivo de la "privatización de las inspecciones laborales», y por el hecho de que «a menudo las condiciones de trabajo [...] no reúnan las normas establecidas», por lo que lo instó «a mejorar la eficacia de las medidas que ha tomado en la esfera de la seguridad y la higiene en el trabajo [...], a hacer más para mejorar todos los aspectos de la higiene y la seguridad ambientales e industriales, y a asegurar que la autoridad pública vigile e inspeccione las condiciones de higiene y seguridad industriales» («Observaciones finales al segundo informe periódico de la República Argentina», 1 de diciembre de 1999, E/C.12/1/Add. 38, párrs. 22 y 37).

No menos importante es, por caso, el razonamiento de la mayoría en «M., D. E. y otro» ${ }^{124}$, en relación con el Comité de los Derechos del Niño y el Comité de

${ }^{124}$ Fallos, 328:4343, de 7 de diciembre de 2005. 
Derechos Humanos. En dicha sentencia dejó sin efecto el fallo por el cual se había condenado a un menor a la pena de prisión perpetua por considerarlo autor del delito de robo con armas en concurso real con el de homicidio criminis causae, en tanto la imposición de dicha pena se fundó en el fracaso del tratamiento tutelar evidenciado a través de la comisión de un nuevo delito, ya que la valoración de un procedimiento en trámite como un factor determinante para elevar el monto de la pena resulta violatoria del principio de inocencia.

En el consid. 30 de tal voto mayoritario rememoró que el Comité de los Derechos del Niño, al analizar el sistema juvenil argentino, expresó su profunda preocupación por el hecho de que las Leyes $10.903^{125}$ y $22.278^{126}$, que se basan en la doctrina de la «situación irregular»" ${ }^{127}$, no distingan, en lo que se refiere a los procedimientos judiciales y el trato, entre los niños que necesitan atención y protección y los niños que tienen conflictos con la justicia («Observaciones Finales: Argentina», CRC.C.15.Add.187, de 9 de octubre del 2002).

A su tiempo, destacó que al derogar la mencionada Ley 10.903 y reemplazarla por la Ley $26.061^{128}$, de «Protección Integral de los Derechos de las Niñas, Niños y Adolescentes», el ordenamiento nacional se pone en línea con las recomendaciones de las Naciones Unidas (haciendo alusión a la Observación General N. ${ }^{\circ} 13$ del Comité de Derechos Humanos) que señalan que los menores deben disfrutar por lo menos de las mismas garantías y protección que se conceden a los adultos en el art. 14 del PIDCP (consid. 31).

Por su parte, citando la OC-17/2002 de la Corte Interamericana de Derechos Humanos, referida a la "Condición Jurídica y Derechos Humanos de los Niños» (párr. 54), el Máximo Tribunal argentino puntualizó que los niños poseen los derechos que corresponden a todos los seres humanos, menores y adultos, y tienen además derechos especiales derivados de su condición, a los que corresponden deberes específicos de la familia, la sociedad y el Estado (consid. 32). Añadió en el consid. siguiente que la Convención Internacional sobre los Derechos del Niño establece los principios fundamentales para el sistema penal de menores en sus arts. 37 y 40, para acotar luego que el Comité de los Derechos

Votaron los doctores Petracchi, Highton de Nolasco, Maqueda, Zaffaroni y Lorenzetti; por su parte, en sendos votos individuales concurrentes se expidieron los ministros Fayt y Argibay.

125 Publicada el 27 de octubre de 1919.

126 B.O. de 28 de agosto de 1980.

127 Paradigma que en dicha causa la Corte tipificó sintéticamente diciendo que «la justicia de menores históricamente se ha caracterizado por un retaceo de principios básicos y elementales que se erige en todo debido proceso, tales como el de legalidad, culpabilidad, presunción de inocencia, proporcionalidad y defensa en juicio» (consid. 27).

128 B.O. de 26 de octubre de 2005. 
del Niño, intérprete de dicha Convención, ha recomendado a los Estados Parte asegurar la total implementación en la justicia penal juvenil a los estándares de ella, en particular a sus arts. 37, 39 y 40, así como a las Reglas Mínimas de las Naciones Unidas para la Administración de la Justicia Juvenil (Reglas de Beijing) y a la Guía de las Naciones Unidas para la Prevención de la Delincuencia Juvenil —Reglas de RIAD— (Dominica CRC/C/15/Add.238. 2004).

Para finalizar esta reseña, no es ocioso recordar que en el consid. 34, el voto colacionado asegura que, en la actualidad, el sistema jurídico de la justicia penal juvenil se encuentra configurado por la Constitución Nacional, la Convención Internacional sobre los Derechos del Niño, la CADH, el PIDCP y el PIDESC, normas que resultan de ineludible consideración al momento de la imposición de penas por hechos cometidos por menores (consid. 34).

\section{LA CONFLICTIVA CUESTIÓN DEL CUMPLIMIENTO DE LAS RECOMENDACIONES DE LA COMISIÓN INTERAMERICANA Y LAS SENTENCIAS DE LA CORTE INTERAMERICANA}

\section{El problema}

En estrecha conexión con el tópico abordado en el apartado anterior, se aprecia que un área neurálgica de todo sistema internacional protectorio de derechos humanos finca en el cabal cumplimiento de las decisiones y sentencias de sus órganos cuasijurisdiccional (en caso de que éste exista ${ }^{129}$ ) y jurisdiccional.

Por razones de brevedad, ceñiremos nuestro señalamiento a ambos órganos de supervisión del esquema tuitivo interamericano.

\section{Recomendaciones de la Comisión Interamericana}

En el particular caso del sistema interamericano, los pronunciamientos de la Comisión no pueden ser ignorados alegremente. Sobre el valor obligatorio de los informes de la Comisión, se ha señalado que la «recomendación» no obligatoria (en los términos de la interpretación que la Corte Interamericana proporcionara al respecto en "Caballero Delgado y Santana", sentencia de 8 de diciembre de

${ }^{129}$ Como sucede en el ámbito interamericano y primigeniamente también acaecía en el marco europeo con la hoy extinta Comisión Europea de Derechos Humanos. 
1995) es aquella emitida por la Comisión en función del art. 51.2 de la CADH, con posterioridad a la presentación del caso ante la Corte; al tiempo que las restantes recomendaciones son obligatorias, concluyendo que una interpretación de buena fe, de acuerdo con el objeto y el fin de la Convención debe afirmar tal obligatoriedad y la percepción acerca de que su incumplimiento genera responsabilidad internacional, puesto que si se desjerarquizase el valor de aquéllas no se estaría coadyuvando a la búsqueda de la perfección del sistema de protección internacional ${ }^{130}$.

Tampoco es una cuestión menor el modo como el art. 33 de la CADH ha sido redactado. En efecto, identifica a la Comisión y a la Corte Interamericanas como "competentes para conocer de los asuntos relacionados con el cumplimiento de los compromisos contraídos por los Estados Partes» en la Convención. Entendemos que se trata de un elemento no exento de relevancia y que lleva también a adjudicar una dosis de imperatividad a los pronunciamientos de uno de los dos órganos que tienen a su cargo la trascendente misión de verificar el cumplimiento de los compromisos asumidos por los Estados en el marco de dicho instrumento internacional.

En torno a ello la Corte Interamericana ha puntualizado que, en función del nombrado art. 33 de la Convención, al ratificar ésta, «los Estados Partes se comprometen a atender las recomendaciones que la Comisión aprueba en sus informes» ${ }^{131}$ — destacado nuestro-.

Es por último indiscutible que de modo correlativo a la obligación individual que adoptan los Estados Partes de la $\mathrm{CADH}$ en el sentido apuntado, afrontan una garantía de carácter colectivo consistente en velar por la preservación de dicho instrumento internacional, uno de cuyos reflejos radica precisamente en procurar que la obligatoriedad de la observancia de las recomendaciones de la Comisión Interamericana sea respetada.

\section{La «voluntad politica» estatal para cumplir los pronunciamientos de la Comisión y la Corte Interamericanas}

Ligado a lo que mencionábamos en el párrafo que cierra el subapartado inmediatamente anterior, CANÇADO TRINDADE subraya que el ejercicio de la

130 Cfr. Albanese, Susana y BidART CAmpos, Germán J., Derecho internacional, derechos humanos y derecho comunitario, Ediar, Buenos Aires, 1998, págs. 148 y 154.

131 Vid. Corte IDH, "Caso Loayza Tamayo», sentencia de 17 de septiembre de 1997, Serie C, N. ${ }^{\circ} 33$, San José de Costa Rica, párr. 81. 
nombrada garantía colectiva por los Estados Partes en la Convención no debería ser sólo reactivo, es decir, cuando se produzca el incumplimiento de una sentencia de la Corte, sino también proactivo, en el sentido de que todos aquéllos deben previamente adoptar medidas positivas de protección de acuerdo con dicho instrumento internacional ${ }^{132}$. Cataloga de «indudable» que una sentencia de la Corte es «cosa juzgada», obligatoria para el Estado demandado en cuestión; pero también es "cosa interpretada», válida erga omnes partes, ya que tiene implicaciones para todos los Estados de la CADH en su deber de prevención ${ }^{133}$.

Desde la acertada óptica que propone Ayala CORAO, las sentencias de la Corte Interamericana son definitivas e inapelables, por lo que, una vez dictadas, devienen firmes y por tanto adquieren cosa juzgada material y formal, lo que a su turno les confiere carácter de sentencias ejecutorias a los fines de su obligatorio cumplimiento y ejecución por el Estado condenado (arts. 67 y 68.1 de la $\mathrm{CADH})^{134}$.

De su lado, es obvio que, más allá de cualquier declaración normativa en el instrumento convencional particularmente acerca de la obligatoriedad de las sentencias para los Estados (v.gr. el art. 68 de la CADH), es imprescindible la convergencia de verdadera voluntad política por parte de éstos en aras de no tornar ilusorios los pronunciamientos, ya que ello no haría más que erosionar los cimientos del edificio protectorio internacional y denotar una actitud censurable en un ámbito de alta sensibilidad como el de la tutela de derechos humanos fundamentales.

Punto trascendente por tener en cuenta es que, entre las pautas a las que los Estados parte de la CADH se comprometen en materia de protección judicial, figura la de "garantizar el cumplimiento, por las autoridades competentes, de toda decisión en que se haya estimado procedente el recurso» (art. 25, 2, 'c').

GARCÍA RAMírEZ ha puntualizado acertadamente que la Corte Interamericana ha manifestado ostentar la potestad de ejercer la supervisión del cumplimiento de sus resoluciones, lo que se enmarca en el plexo de facultades inheren-

132 Cfr. Cançado Trindade, Antônio A., «Anexo 21: Presentación del Presidente de la Corte Interamericana de Derechos Humanos ante el Consejo Permanente de la Organización de los Estados Americanos (OEA)», de 16 de octubre de 2002, en el mismo autor, El sistema interamericano de protección de los derechos humanos en el umbral del siglo XXI, Memoria del Seminario realizado los días 23 y 24 de noviembre de 1999, T. ${ }^{\circ}$ II, 2. ${ }^{a}$ ed., Corte Interamericana de Derechos Humanos, San José de Costa Rica, mayo de 2003, pág. 920.

133 Ídem.

134 Ayala Corao, Carlos M., «La ejecución de sentencias de la Corte Interamericana de Derechos Humanos», Estudios Constitucionales, Año 5, N. ${ }^{\circ}$, Centro de Estudios Constitucionales, Universidad de Talca, Santiago de Chile, 2007, pág. 134. 
tes a sus atribuciones jurisdiccionales, no pudiendo entonces desentenderse de la suerte que aquéllas corran ${ }^{135}$. Por su parte, y como añade el citado autor, el carácter imperativo de dichas resoluciones y la sujeción del cumplimiento a la supervisión del Tribunal constituyen efectos del principio pacta sunt servanda ${ }^{136}$.

Dichas facultades supervisoras de la Corte se ejercen sobre sentencias que serán ejecutadas en el Estado condenado, por lo que lo ideal sería que en éstos existieran dispositivos legales que permitan agilizar dicha pretensión de cumplimiento compulsivo de las mismas en orden a lograr su verdadera y completa efectividad.

En el caso argentino correspondería que la Corte Suprema mantenga la impronta que — en general — ha inoculado a sus sentencias frente a las decisiones de la Corte Interamericana y unifique discursivamente su posición jurisdiccional ante los pronunciamientos de la Comisión Interamericana, marco este último en el que si bien ha dado un paso adelante, lo ideal sería avanzar hacia la adjudicación de una mayor dosis de vinculatoriedad que exceda el mero peso interpretativo.

Es que, en definitiva, no cabe soslayar que tales directivas emanan de un órgano principal de la Organización de los Estados Americanos (OEA), cuya función consiste en promover la observancia y la defensa de los derechos humanos en el hemisferio ${ }^{137}$ (vid. art. 106 de la Carta de dicha Organización), sin olvidar, ya desde otra vertiente argumental, que no es sencillo predicar la sustentabilidad jurídica del razonamiento estatal por medio del cual asegura no tener el deber de cumplir las recomendaciones de la Comisión, pues en tal caso, los efectos, el alcance y la suerte final de ellas quedarían totalmente a merced y criterio de la propia parte remisa.

\section{Corolario}

Como lógica consecuencia de lo afirmado precedentemente, y antes de dar paso a las observaciones de cierre de este trabajo, no puede dejar de resaltarse que

135 GarCía Ramírez, Sergio, en la Presentación del libro de Rey Cantor, Ernesto y Rey Anaya, Ángela Margarita, Medidas provisionales y medidas cautelares en el sistema interamericano de derechos humanos, Universidad Nacional Autónoma de México (Instituto de Investigaciones Jurídicas) e Instituto Interamericano de Derechos Humanos, Temis, Bogotá, 2005, pág. XLIV.

136 Ibid., pág. XLV.

137 Cfr. el relato de Cançado Trindade, Antônio A., del «Informe: Bases para un Proyecto de Protocolo a la Convención Americana sobre Derechos Humanos, para fortalecer su mecanismo de protección", op. cit. en nota 132 (El sistema interamericano de protección de los derechos humanos en el...), pág. 12. 
una cuestión vital para la efectividad de la protección internacional de los derechos humanos estriba en la necesidad de que los países comprometidos conciban normativamente y articulen en la práctica mecanismos idóneos (asegurando su cabal operatividad) para acatar y cumplir las sentencias dictadas por los tribunales internacionales de derechos humanos, asignando a dichas resoluciones fuerza ejecutiva y ejecutoria.

Es decir que, voluntad política mediante, sería útil que existiera una normativa que de modo claro paute el procedimiento para cumplir las recomendaciones de la Comisión Interamericana y los pronunciamientos de la Corte Interamericana, al modo como existe mutatis mutandi en Costa Rica, en el «Convenio de sede entre el Gobierno de la República de Costa Rica y la Corte Interamericana de Derechos Humanos», de 10 de septiembre de 1981, ratificado por Ley 6.889; Colombia, por medio de la Ley 288, de 5 de julio de 1996, y el Decreto 321, de 25 de febrero de 2000; y Perú, art. 115 del Código Procesal Constitucional —aprobado por Ley 28.237, publicada el 31 de mayo de 2004- y Ley 27.775, publicada el 7 de julio de 2002.

En sentido convergente, aunque todavía en trance de aprobación, resulta altamente positivo que en el proyecto chileno de "Acciones protectoras de derechos fundamentales» — en debate en la Comisión de Derechos Humanos, Nacionalidad y Ciudadanía de la Cámara de Diputados de la Nación ${ }^{138}$-, se contemple específicamente en su art. 128, párrafo $1 .^{\circ}$, que las «sentencias de la Corte internacional o supranacional en materia de derechos humanos a la que el Estado de Chile le haya reconocido jurisdicción contenciosa vinculante son de obligatorio cumplimiento por los órganos del Estado de Chile» (destacado añadido), además de pautar en los párrafos $2 .^{\circ}$ y $3 .^{\circ}$ de aquella cláusula las líneas básicas del procedimiento que debe cumplir la Corte Suprema de Justicia para la ejecución de semejantes resoluciones y de las sentencias de término de cualquier otro Tribunal o Corte internacional o supranacional en materia de derechos humanos a los que Chile les hubiera reconocido jurisdicción vinculante.

\section{EPÍLOGO}

No cabe duda que las conexiones e interferencias del derecho interno y el derecho internacional de los derechos humanos son diversas y complejas, algunas de las cuales, y en función de lo examinado en esta contribución, nos provocan las siguientes apreciaciones de cierre:

138 Según información recabada en octubre de 2007. 
1. Una de las facetas sustanciales de las relaciones entre el derecho internacional y el derecho interno se traduce en que la eficacia real del primero depende en buena medida de la fidelidad con que los derechos nacionales se conformen a las normas internacionales y les den efecto ${ }^{139}$.

En particular respecto del derecho internacional de los derechos humanos, la creciente trascendencia que recepta su convergencia con el derecho vernáculo requiere una articulación que retroalimente a ambos y los complemente para coadyuvar a una vigorización real del modelo tuitivo de derechos fundamentales.

Tales premisas confirman que la medular problemática de los derechos humanos es una incumbencia - y debe ser una preocupación- concurrente o compartida entre las jurisdicciones estatales y la transnacional.

2. Sin embargo, nada se descubre al recordar que la interacción de los tribunales nacionales y los internacionales en materia de derechos humanos se mueve al compás de una lógica compleja y genera una trama de relaciones en ocasiones conflictiva.

Como afirma SAGÜÉS, ello obecede a «factores sociológicos y gnoseológicos de desinformación, rechazo, inadaptación, desnaturalización, hedonismo y narcisismo, a más de los ideológico-políticos, que obstaculizan a menudo el acatamiento de la justicia doméstica a la internacional. A su turno, ésta puede padecer de potenciales defectos de comprensión de las realidades locales, cuando no de intereses también ideológicos o de complejos de superioridad. No hay que descartar en ella, paralelamente, fallos altruistas - pero imprevisores - que no midan con cuidado los efectos expansivos que puedan tener en el mundo jurídico» ${ }^{140}$.

Éstos y otros condimentos de una cuestión de actualidad permanente llevan a reiterar que la consolidación de una convergencia sustentable de ambas instancias jurisdiccionales se presenta como una necesidad inaplazable, que pasa a simbolizar uno de los retos cruciales a los que se enfrenta la cabal protección del ser humano en los ámbitos interno e internacional.

3. En Argentina es indisimulable el gravitante impacto que la reforma constitucional de 1994 ha provocado en el campo de los derechos humanos. Así, la dotación de jerarquía constitucional a un nutrido plexo de instrumentos in-

139 Cfr. PAStOr Ridruejo, José A., Curso de derecho internacional público y organizaciones internacionales, 10. ${ }^{a}$ ed., Tecnos, Madrid, 2006, pág. 165.

140 SAGÜÉs, Néstor P., "Las relaciones entre los tribunales internacionales y los tribunales nacionales en materia de derechos humanos. Experiencias en Latinoamérica», Ius et Praxis - Derecho en la Región, Año 9, N. ${ }^{\circ}$, Universidad de Talca, Facultad de Ciencias Jurídicas y Sociales, Talca, 2003, pág. 220. 
ternacionales sobre derechos humanos y los recipiendarios ex post de tal valía; la instauración de los principios pro homine o favor libertatis y pro actione; el añadido de una dimensión material, complementaria de la formal, al principio de igualdad; la necesidad de su aseguramiento a través de acciones positivas; $y$ la inexcusable implicación de todas las autoridades públicas en tales menesteres, incluidos obviamente los magistrados judiciales, forman un compacto de factores envueltos y recorridos por el caudal axiológico que les suministra el imperativo preambular de «afianzar la justicia», que compromete al Estado argentino más allá de las palabras y lo impele a volcar todos los esfuerzos y recursos posibles en el cabal cumplimiento de las obligaciones internacionalmente asumidas.

4. Un escenario de tales características supone, entre otras consecuencias y por imperio de la modificación del sistema de fuentes que en el ordenamiento jurídico ha generado la última innovación constitucional, la extensión formal y material del parámetro de control de constitucionalidad, en virtud de lo cual y para verificar si supera satisfactoriamente el examen de constitucionalidad, la normativa subconstitucional debe ser analizada a la luz de la Ley Fundamental, de los instrumentos internacionales sobre derechos humanos con valencia homóloga a ésta y de la interpretación autorizada que de ellos hagan los órganos internacionales competentes.

5. No puede perderse de vista que, entre otros puntos de interés, el neoconstitucionalismo ha modificado el marco teórico del derecho constitucional, surgiendo una nueva dogmática constitucional caracterizada por la complejización del Derecho, el que se tornó menos previsible, con la convergencia de valores, principios y conceptos jurídicos indeterminados que interactúan con reglas, principios y valores surgentes del derecho internacional de los derechos humanos.

Tal cuadro de situación también ha llevado a que la tarea judicial se torne más compleja, entre otras cosas, por la multiplicidad de fuentes jurídicas que el juez debe conocer y manejar, lo que impone un replanteo del rol jurisdiccional, exigiendo un aggiornamento de la estructura de pensamiento del magistrado y de su posicionamiento frente a ciertas causas dilemáticas, colocándolo ante la necesidad de una relectura de diversas cuestiones jurídicas no ya a la luz de rígidos parámetros del proceso civil, sino de los postulados del derecho constitucional, el procesal constitucional y el internacional de los derechos humanos.

6. En el marco recientemente descripto se impone que la tarea interpretativa que desenvuelve la judicatura se conforme no sólo a la Constitución sino también al derecho internacional de los derechos humanos, labor que exige conocer y aplicar los estándares emergentes de, inter alia, los repertorios de pronunciamientos de la Comisión Interamericana y la jurisprudencia de la Corte Interamericana, en sus precedentes jurisdiccionales y sus opiniones consultivas. 
Como si se tratara de la misma escena de idéntica película, aunque filmada desde otro ángulo, aquella premisa de interpretación conforme al derecho internacional de los derechos humanos a la que referíamos ha sido reivindicada también por la propia Corte Interamericana, al poner en cabeza de los poderes judiciales de los Estados la obligación de llevar adelante el 'control de convencionalidad' (caso "Almonacid Arellano») entre las normas jurídicas internas que aplican en los casos concretos y la $\mathrm{CADH}$, debiendo tenerse en cuenta en tal faena no solamente la literalidad de dicho instrumento internacional sino la interpretación que del mismo ha llevado adelante el citado tribunal interamericano en su papel de intérprete último y final.

La delicada misión que la magistratura judicial ostenta como último reducto para la defensa y efectivización de los derechos fundamentales en el ámbito vernáculo deberá ser afrontada y desplegada conociendo y asumiendo la importancia axiológica de las fuentes jurídicas internacionales (instrumentos internacionales sobre derechos humanos, costumbres internacionales consolidadas y principios generales del derecho de las naciones civilizadas), las que habrán de emplearse como guía en la trascendente tarea de interpretación y aplicación de los preceptos de la Ley Fundamental.

No hacerlo así podría suponer, más allá de una grave despreocupación por el resguardo de la dignidad humana, que el Estado incurra en responsabilidad internacional, pues por ejemplo respecto del orden jurídico interamericano, ser parte de la $\mathrm{CADH}$ genera tanto un deber de respeto a los derechos humanos como un deber de garantía de éstos.

7. La Corte Suprema de Justicia de la Nación exhibe, sobre todo (aunque no exclusivamente) a partir de su actual conformación, una propensión a receptar en sus pronunciamientos los dictados del derecho internacional de los derechos humanos, tanto en lo que hace al respeto por las cláusulas de los instrumentos internacionales como a la interpretación de los órganos de supervisión de los distintos sistemas protectorios en la materia, interamericanos (Corte Interamericana) y universales (Comité de los Derechos del Niño, Comité de Derechos Humanos, Comité de Derechos Económicos, Sociales y Culturales).

No sólo lo ha concretado en materia primordialmente vinculada a los derechos civiles y políticos, sino también en torno a los derechos económicos, sociales y culturales, generando un aporte para eliminar los obstáculos que suelen impedir el goce real de éstos últimos, que no tienen menor entidad que los civiles y políticos y que, por tanto, no pueden continuar mediatizados al influjo de un malentendido concepto de progresividad, ya que ésta no significa letargo o pasividad estatales sine die. Punto de interés por resolver al respecto es el límite del activismo judicial en la materia, sobre el que si bien no podemos abundar aquí, 
al menos sí creemos oportuno afirmar que la Corte está suficientemente habilitada, como hipótesis de mínima, a garantizar el contenido esencial del derecho en cuestión, sin invadir irrazonablemente esferas propias de otros poderes del Estado pero tampoco abdicar de su eminente misión protectoria de los derechos fundamentales.

Además de la línea de doctrina judicial del Alto Tribunal Nacional, la citada tendencia se hace igualmente perceptible en ciertas acordadas en las que subyace una clara impronta que muestra el sitio preferente que la problemática de los derechos humanos ocupa en su agenda de preocupaciones temáticas.

8. La plausibilidad del esquema de pensamiento y acción que en el espectro de los derechos humanos ha venido exhibiendo la Corte Suprema, no ha impedido que el temperamento asumido en ciertos fallos genere algunas dudas y posiciones críticas en determinados sectores de la doctrina.

Por ejemplo, se le ha cuestionado la suerte de estándar dual que viene modelando al mostrarse permeable a reabrir procesos en contra del denominado "terrorismo de Estado" y refractaria a hacerlo en causas contra lo que se ha dado en llamar el «terrorismo subversivo» (v.gr., lo resuelto, respectivamente, en «Arancibia Clavel» o «Simón» y «Lariz Iriondo»); o se ha advertido sobre la controversia dialéctica que entre los propios miembros del Tribunal (y en el ámbito doctrinario) ha originado la declaración de inconstitucionalidad de los decretos de indulto en crímenes de lesa humanidad vis-à-vis las garantías constitucionales de la cosa juzgada y de ne bis in idem ("Mazzeo»), que seguramente seguirá causando lecturas dispares en el plano autoral en tanto la cuestión es controversial.

9. En punto a la cotización jurídica que la Corte Suprema adjudica a las sentencias de la Corte Interamericana (también a las opiniones consultivas) y a las directivas de la Comisión Interamericana, es necesario que mantenga la impronta que - en general — ha inoculado a sus fallos frente a las decisiones del tribunal interamericano y que unifique discursivamente su posición jurisdiccional ante los pronunciamientos de la Comisión, adjudicándoles un mayor grado de obligatoriedad y no sólo valencia interpretativa, aunque debe rescatarse como un avance la posición que en «Simón» ha trasuntado sobre el particular, retomando - aunque con mayores precisión terminológica y densidad jurídica- la línea diseñada en "Bramajo».

10. Una cuestión central para lograr la efectividad de la protección internacional de los derechos humanos, más allá de pugnar por supuesto por evitar infracciones que puedan entrañar responsabilidad internacional y en su caso cumplir voluntariamente las sentencias internacionales de condena, radica en que el Estado argentino diseñe normativamente mecanismos idóneos para eje- 
cutar los fallos de la Corte Interamericana (recordar lo sucedido en «Cantos»" ${ }^{141}$ ) y dar cumplimiento a los informes de la Comisión Interamericana.

Naturalmente, una genuina voluntad política deberá ser el combustible que dé origen y mantenga en movimiento a semejante plexo normativo que potencialmente se dicte, para evitar que el dispositivo legal creado sea sólo una muestra gatopardista que cambie todo para que todo continúe igual. Aunque parezca obvio, nunca está de más recordar que las leyes, por sí mismas, no solucionan nada.

El acatamiento de aquellos pronunciamientos, como pone de manifiesto Ayala CORAO aunque refiriéndose específicamente a las sentencias de la Corte Interamericana, forma parte de las reglas básicas del derecho internacional en todo Estado de Derecho y es requisito esencial para la garantía efectiva de la protección de la persona humana ${ }^{142}$.

11. Como la Corte Interamericana de Derechos Humanos ha enfatizado, los tratados modernos sobre derechos humanos tienen un carácter especial, cuyos objeto y fin confluyen en un punto común: la protección de los derechos fundamentales de los seres humanos, con independencia de su nacionalidad, tanto frente a su propio Estado cuanto a los restantes Estados contratantes. Es decir, no son tratados multilaterales del tipo tradicional, concluidos en función de un intercambio recíproco de derechos, para el beneficio mutuo de los Estados contratantes; por el contrario, cuando los Estados aprueban un tratado sobre derechos humanos quedan sometidos a un ordenamiento legal dentro del cual asumen diversas obligaciones en relación con los individuos bajo su jurisdicción y no frente a otros Estados $^{143}$.

Siendo así, el no pocas veces contingente voluntarismo político de los Estados para graduar según sus conveniencias y avatares del momento el nivel de permeabilidad hacia las decisiones de los órganos protectorios internacionales de derechos humanos, no es precisamente la solución ideal que exigen el necesario respeto por la dignidad de la persona humana, valor básico que los fundamenta, y la obligatoriedad de honrar los compromisos asumidos internacionalmente en

141 Ver supra, nota 113.

142 Ayala Corao, Carlos M., op. cit., pág. 133.

143 Cfr., Corte IDH, OC-2/82, cit., párr. 29, pág. 44.

Un análisis de tal opinión consultiva puede verse en Bazán, Víctor, «La Convención Americana sobre Derechos Humanos y el efecto de las reservas respecto de su entrada en vigencia: a propósito de la OC-2/82 de la Corte Interamericana de Derechos Humanos», en BIDART CAMPOS, Germán et al., Derechos humanos. Corte Interamericana, Ediciones Jurídicas Cuyo, T. ${ }^{\circ}$ I, Mendoza, 2000, págs. 91/165. 
tan sensible terreno, que están recorridos transversalmente por el principio fundamental de la buena fe.

\section{Title}

THE SUPREME COURT OF JUSTICE OF ARGENTINA AND THEIR ROLE IN THE ARTICULATION OF THE INTERNATIONAL LAW OF THE HUMAN RIGHTS AND THE INTERNAL LAW

\section{Summary}

I. PLAN OF THE WORK. - II. PRELIMINARY APPRECIATIONS. - III. THE CONSTITUTIONAL REFORM OF 1994 AND THEIR IMPACT IN THE FIELD OF THE HUMAN RIGHTS. - IV. THE JUDGES AND THE CONSTITUTIONAL STATE GOBERVEN BY LAW. - V. THE SUPREME COURT OF ARGENTINEAN JUSTICE AND THEIR RECENT JURISPRUDENCE IN MATTER OF HUMAN RIGHTS: VI. THE EXHIBITED APPROACHES FOR THE SUPREME COURT IN FRONT OF THE PRONOUNCEMENTS OF THE COURT AND THE INTERAMERICAN COMMISSION OF HUMAN RIGHTS AND OTHER COMPETENT INTERNATIONAL ORGANS IN THE MATTER. VII. THE CONFLICTING QUESTION OF THE EXECUTION OF THE RECOMMENDATIONS OF THE INTERAMERICAN COMMISSION AND THE SENTENCES OF THE INTERAMERICAN COURT: VIII. EPILOGUE.

Palabras clave

Derecho internacional, Derecho interno, Derechos humanos.

Key words

International Law, Nacional Law, Human Rights 